\title{
Effects of soil rewetting and thawing on soil gas fluxes: a review of current literature and suggestions for future research
}

\author{
D.-G. Kim ${ }^{1}$, R. Vargas $^{2,3}$, B. Bond-Lamberty ${ }^{4}$, and M. R. Turetsky ${ }^{5}$ \\ ${ }^{1}$ Landcare Research, Palmerston North 4442, New Zealand \\ ${ }^{2}$ Departamento de Biología de la Conservación, Centro de Investigación Científica y de Educación Superior de Ensenada \\ (CICESE), Ensenada, BC, Mexico \\ ${ }^{3}$ Department of Plant and Soil Sciences, Delaware Environmental Institute, University of Delaware, Newark, DE 19717, USA \\ ${ }^{4}$ Pacific Northwest National Laboratory, Joint Global Change Research Institute at the University of Maryland - \\ College Park, College Park, MD 20740, USA \\ ${ }^{5}$ Department of Integrative Biology, University of Guelph, Guelph, ON, Canada
}

Correspondence to: D.-G. Kim (donggillkim@gmail.com)

Received: 31 August 2011 - Published in Biogeosciences Discuss.: 4 October 2011

Revised: 30 May 2012 - Accepted: 3 June 2012 - Published: 9 July 2012

\begin{abstract}
The rewetting of dry soils and the thawing of frozen soils are short-term, transitional phenomena in terms of hydrology and the thermodynamics of soil systems. The impact of these short-term phenomena on larger scale ecosystem fluxes is increasingly recognized, and a growing number of studies show that these events affect fluxes of soil gases such as carbon dioxide $\left(\mathrm{CO}_{2}\right)$, methane $\left(\mathrm{CH}_{4}\right)$, nitrous oxide $\left(\mathrm{N}_{2} \mathrm{O}\right)$, ammonia $\left(\mathrm{NH}_{3}\right)$ and nitric oxide $(\mathrm{NO})$. Global climate models predict that future climatic change is likely to alter the frequency and intensity of drying-rewetting events and thawing of frozen soils. These future scenarios highlight the importance of understanding how rewetting and thawing will influence dynamics of these soil gases. This study summarizes findings using a new database containing 338 studies conducted from 1956 to 2011, and highlights open research questions. The database revealed conflicting results following rewetting and thawing in various terrestrial ecosystems and among soil gases, ranging from large increases in fluxes to non-significant changes. Studies reporting lower gas fluxes before rewetting tended to find higher post-rewetting fluxes for $\mathrm{CO}_{2}, \mathrm{~N}_{2} \mathrm{O}$ and $\mathrm{NO}$; in addition, increases in $\mathrm{N}_{2} \mathrm{O}$ flux following thawing were greater in warmer climate regions. We discuss possible mechanisms and controls that regulate flux responses, and recommend that a high temporal resolution of flux measurements is critical to capture rapid changes in gas fluxes after these soil perturbations. Finally, we propose that future studies should investigate the interactions
\end{abstract}

between biological (i.e., microbial community and gas production) and physical (i.e., porosity, diffusivity, dissolution) changes in soil gas fluxes, apply techniques to capture rapid changes (i.e., automated measurements), and explore synergistic experimental and modelling approaches.

\section{Introduction}

The rewetting of dry soils and the thawing of frozen soils represent abrupt step changes in soil biophysical conditions, with critical implications for biogeochemical cycling. From an organismal perspective, soil rewetting and thawing have similar effects because both processes increase the availability of soil water, rehydrate cells, increase microbial metabolism, and mobilize nutrients. Both processes are also relatively transient, non-stationary, and the duration of individual rewetting and thawing events varies as a result of the effects of local climatic conditions, topography, drainage, vegetation type, and soil thermal properties (Balser and Firestone, 2005; Vargas et al., 2010b). The sudden flush of water and nutrients that occurs after rewetting and thawing induces changes in plant and microbial activity, with organisms shifting rapidly from dormant or senescent states to active ones (Kieft et al., 1987; Schimel and Clein, 1996; Kemmitt et al., 2008). 
It is important to understand the change in magnitude of fluxes from soil gases (i.e., $\mathrm{CO}_{2}, \mathrm{CH}_{4}, \mathrm{~N}_{2} \mathrm{O}, \mathrm{NO}$ and $\mathrm{NH}_{3}$ ) following rewetting and thawing events. These fluxes are either by-products, intermediates, or end-products of soilrelated microbial processes involved in $\mathrm{C}$ and $\mathrm{N}$ dynamics in soils. These gases also play crucial roles in atmospheric chemistry, with the notable characteristic that $\mathrm{CO}_{2}, \mathrm{CH}_{4}$ and $\mathrm{N}_{2} \mathrm{O}$ are greenhouse gases (GHG). In addition, soil $\mathrm{NH}_{3}$ emissions are of considerable interest since they constitute a significant loss of $\mathrm{N}$ in agricultural soils (Nelson, 1982; Francis et al., 2008), causing soil acidification (Van der Eerden et al., 1998; Rennenberg and Gessler, 1999), eutrophication through atmospheric deposition (Bobbink et al., 1992), and are an indirect source of $\mathrm{N}_{2} \mathrm{O}$ (Martikainen, 1985). Nitric oxide is indirectly involved in global warming and contributes to the net production of radiatively active tropospheric ozone and the formation of acid rain (Williams et al., 1992). Nitric oxide is also important in controlling the oxidizing capacity of the troposphere, thereby affecting the fate of carbon monoxide, $\mathrm{CH}_{4}$ and nonmethane hydrocarbons (Liu et al., 1987).

Future climatic change is likely to alter the frequency and intensity of drying-rewetting events (Meehl et al., 2006; Sheffield and Wood, 2008; Sinha and Cherkauer, 2010). Furthermore, the frequency and intensity of soil frost (i.e., freeze-thaw cycles and annual soil freezing days) are also likely to change since warming could lead to a reduction in the thickness of the insulating snowpack and thus colder winter soil temperatures (Henry, 2008; Gu et al., 2008; Blankinship and Hart, 2012). It is thus important to understand how soil rewetting and thawing influence soil GHG fluxes, because these events could influence substantially annual gas budgets, and increases or decreases in these fluxes may contribute to either positive or negative feedbacks to climate change.

While abrupt increases in soil $\mathrm{CO}_{2}, \mathrm{~N}_{2} \mathrm{O}, \mathrm{NH}_{3}$ and $\mathrm{NO}$ fluxes following rewetting are commonly observed in various agricultural lands and natural lands (Birch, 1958; Priemé and Christensen, 2001; Saetre and Stark, 2005), rewetting can either increase (Moore et al., 1998; Knorr et al., 2008) or inhibit (Kessavalou et al., 1998; Teh et al., 2005) $\mathrm{CH}_{4}$ oxidation. Similarly, increases in $\mathrm{CO}_{2}, \mathrm{CH}_{4}$ and $\mathrm{N}_{2} \mathrm{O}$ fluxes following soil thawing have been shown to affect total annual gas budgets (Röver et al., 1998; Papen and Butterbach-Bahl, 1999). Despite a growing number of studies, there are still many uncertainties in our understanding of the mechanisms and impacts of changing rainfall patterns and freeze-thaw cycles on annual gas budgets. These uncertainties are exacerbated by the coarse temporal sampling resolution of most flux measurements that do not capture the complete pulse dynamics (Groffman et al., 2006; Muhr et al., 2009). Additional uncertainties arise from unrealistic experiments of dry-wet and freeze-thaw events (as discussed in Henry, 2007; Jentsch et al., 2007). These experiments simulate events that are out of the expected range of soil temperature and soil moisture (i.e., $>95 \% \mathrm{CI}$ ) in current and past climate conditions, so the results are difficult to apply under current climate conditions.

The growing number of studies on the individual effects of rewetting and thawing specifically on $\mathrm{CO}_{2}$ and $\mathrm{N}_{2} \mathrm{O}$ fluxes have been the focus of several reviews (Jarvis et al., 2007; Henry, 2007; Matzner and Borken, 2008; Borken and Matzner, 2009; Groffman et al., 2009; Blankinship and Hart, 2012). This review is novel in that it takes a comprehensive approach to dealing with the effects of both rewetting and thawing on multiple soil gas fluxes (i.e., $\mathrm{CO}_{2}, \mathrm{CH}_{4}, \mathrm{~N}_{2} \mathrm{O}$, $\mathrm{NO}$ and $\mathrm{NH}_{3}$ ), and provides a new open-access database of published studies conducted between 1956 and $2011(n=338)$. Our objectives were to: (1) summarize the effects of rewetting and thawing on multiple soil gas fluxes (i.e., $\mathrm{CO}_{2}, \mathrm{CH}_{4}$, $\mathrm{N}_{2} \mathrm{O}$, NO and $\mathrm{NH}_{3}$ ) and highlight common patterns across studies; (2) discuss the potential underlying mechanisms and drivers of variation of soil gas fluxes following rewetting and thawing; and (3) identify knowledge gaps and highlight future research questions.

\section{Methodology}

\subsection{Data collection}

Data on changes in gas fluxes of $\mathrm{CO}_{2}, \mathrm{CH}_{4}, \mathrm{~N}_{2} \mathrm{O}$, NO and $\mathrm{NH}_{3}$ following rewetting and thawing were acquired by searching existing refereed literature published between 1950 and 2011 using Web of Science and Google Scholar with search terms such as "rewetting", "thawing", "peak flux", "peak emission" and name of gases. Studies with field observations of rewetting of dry soils include events caused by natural rainfall, simulated rainfall in natural ecosystems, and irrigation in agricultural lands. Similarly, studies of thawing of frozen soils include field observations of natural thawing, simulated freezing-thawing events (i.e., thawing of simulated frozen soil by snow removal, simulated freezingthawing cycles in the laboratory), and thawing of seasonal ice in temperate and high latitude regions. We did not include the long-term effects of changing active layer depths caused by permafrost thaw in this review, as changes in gas fluxes in response to permafrost thaw are affected by both changing soil and plant successional processes (Turetsky et al., 2002; Christensen et al., 2004; Walter et al., 2006; Anisimov, 2007; Turetsky et al., 2007). We define response as the behavior or reaction dynamics of the different soil gas fluxes that result from rewetting or thawing of soils. The responses may vary in intensity, magnitude and/or duration, depending on the gas analyzed.

The resulting database comprised 222 field and laboratory observations $\left(\mathrm{CO}_{2} n=54, \mathrm{CH}_{4} n=15, \mathrm{~N}_{2} \mathrm{O} n=58\right.$, NO $n=87$ and $\mathrm{NH}_{3} n=8$ ) focused on rewetting of dry soils, and 116 field and laboratory observations $\left(\mathrm{CO}_{2} n=23\right.$, $\mathrm{CH}_{4} n=10, \mathrm{~N}_{2} \mathrm{O} n=78$, NO $n=5$ ) focused on thawing of 
frozen soils. The version of this database used for this study (v.1.0) has been archived at the Oak Ridge National Laboratory Distributed Active Archive Center (http://daac.ornl.gov/ SOILS/guides/global_rtsg_flux_v1.html; A Global Database of Gas Fluxes from Soils after Rewetting or Thawing, Version 1.0).

\subsection{Determining gas flux change rates and compiled dataset analysis}

For studies that reported temporal changes in gas flux rates pre- and post rewetting or thawing events in a single treatment (Fig. 1a), we calculated the change in gas flux rates (\%) using the flux values observed before the event (i.e., rewetting or thawing) along with peak flux values that occurred post-event:

Flux change $=\frac{(\text { Peak flux } \text { post-event })-\left(\text { Flux }_{\text {pre-event }}\right)}{\left(\text { Flux }_{\text {pre-event }}\right)} \times 100 \%$

where Flux change (\%) is the relative effect of the event on

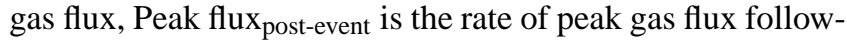
ing the event, and Fluxpre-event is the rate of gas flux before the event (i.e., rewetting or thawing).

For studies that compared gas fluxes between simulated (representing either rewetting or thawing treatments) and control treatments (Fig. 1b), we calculated changes in gas fluxes exactly as in Eq. (1), but using Peak flux $\operatorname{Exp}_{\text {(the }}$ rate of peak gas flux following the treatment; substituted for Flux $_{\text {post-event }}$ ) and Flux Control (the rate of gas flux observed at the control at the time peak gas flux; substituted for Peak (lux $x_{\text {pre-event }}$ ).

Peak flux period was determined by identifying duration of increased flux of soil gases following soil rewetting and thawing in field (Fig. 1a) and laboratory experiments (Fig. 1b). The dataset prepared for this manuscript ( $n=338$ studies) is dominated by experiments using discrete measurements that miss the highly detailed patterns of soil gas fluxes following rewetting or thawing as shown in Fig. 2. Thus, we used Eq. (1) as a proxy to represent a simplified response based on discrete measurements of soil gas fluxes. It is important to recognize that discrete measurements introduce uncertainty in calculating flux changes as it is difficult to determined the peak flux period, as seen in Fig. 2. If gas fluxes were presented only in a figure without numeric values reported in the original text or tables, we calculated the corresponding values from the figure using the software Acrobat ${ }^{\circledR}$ 8 Professional ver. 8.2 (Adobe Systems, Inc. San Jose, CA, USA).

The relationship between rate change of soil gas fluxes following rewetting and thawing and Flux $\mathrm{x}_{\text {pre-event }}$ and mean annual temperature was determined by fitting linear models, with logarithmic transformations when necessary for heteroschedasticity. All analyses were performed using R 2.14.1. (R Development Core Team, 2011).
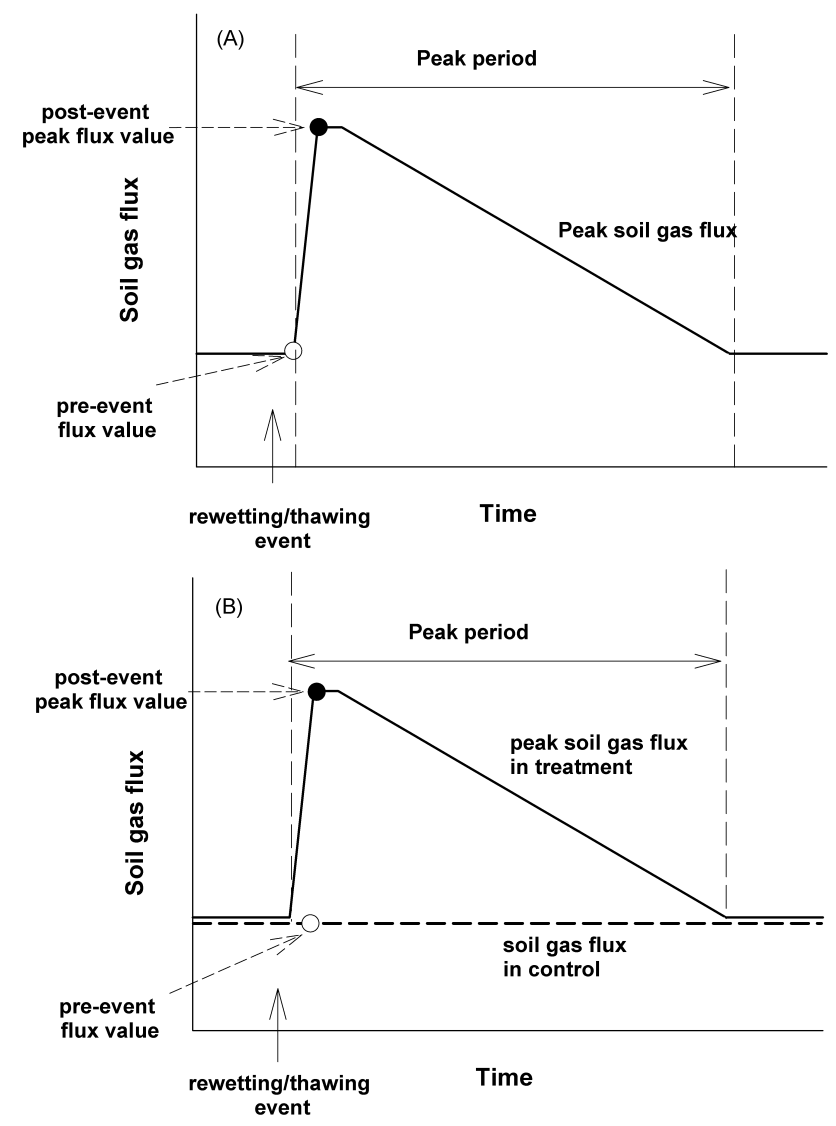

Fig. 1. Simplified hypothetical figures representing peak soil gas flux in rewetting of dry soils and thawing of frozen soils and peak flux period. Peak gas flux occurred in natural rewetting or thawing event (solid line) and pre-event flux value (white dot) and post-event peak flux value (black dot) used to determine flux change rate (A); peak gas flux occurred in rewetting or thawing treatment (solid line) and gas flux in control (dot line) and pre-event flux value (white dot, the flux value in control when post-event peak flux value is read) and post-event flux value (black dot) used to determine flux change rate (B). The figure is a simplification of the response and does not reflect the full dynamics of a pulse response as shown in Fig. 2.

\section{A review of the effect of rewetting and thawing on soil gas fluxes}

For each soil gas we discuss below: (1) how rewetting and thawing events influence gas fluxes in various ecosystems and experimental designs; and (2) the likely mechanisms and environmental controls underlying the observed patterns. We define response as the behaviour or change in soil gas fluxes (see Fig. 1, Eq. 1) that results from rewetting or thawing of soils. 


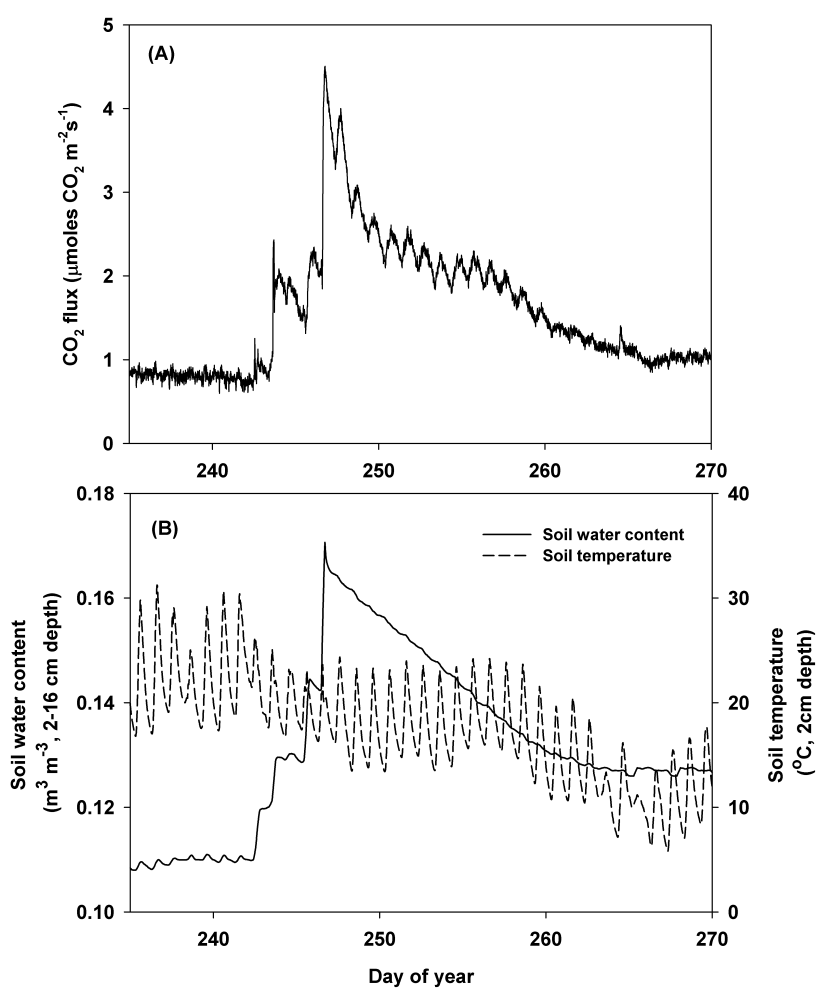

Fig. 2. High temporal resolution (hourly data) of soil $\mathrm{CO}_{2}$ flux dynamics before and after a rewetting event (A); and soil water content (2-16 cm depth) and soil temperature ( $2 \mathrm{~cm}$ depth) dynamics during the same dates of the soil $\mathrm{CO}_{2}$ flux measurements (B). Measurements were done during the year 2008 at the San Jacinto Mountains James Reserve, CA, USA (Vargas et al., 2010b).

\subsection{Patterns of soil gas flux response to rewetting and thawing}

\subsubsection{Carbon dioxide}

Soil surface $\mathrm{CO}_{2}$ flux provides an integrated result of biological $\mathrm{CO}_{2}$ production throughout the soil column, changes in soil $\mathrm{CO}_{2}$ diffusivity in the soil profile, and in some areas geological processes (Raich and Schlesinger, 1992; Schlesinger and Andrews, 2000). Carbon dioxide is the dominant loss pathway in most terrestrial ecosystems, as well as the most important GHG in the atmosphere. Our database contains 77 studies that measured $\mathrm{CO}_{2}$ and are equivalent to $\sim 23 \%$ of all studies. This shows that $\mathrm{CO}_{2}$ is the soil gas that has received the third most attention for studying the effects of rewetting and thawing of soils.

Increases in $\mathrm{CO}_{2}$ flux following rewetting of dry soils have been reported in multiple terrestrial ecosystems and various land-use types, including cropland (Kessavalou et al., 1998), grazing pasture (Xu and Baldocchi, 2004), forest (Kim et al., 2010b), grassland (Joos et al., 2010), savannas (Castaldi et al., 2010), and desert (Sponseller and Fisher, 2008). Incubation experiments have yielded similar patterns, showing
$\mathrm{CO}_{2}$ flux increases after rewetting in soils from cropland (Beare et al., 2009), grazing pasture (Wu et al., 2010b), forest (Fierer and Schimel, 2003), grassland (Xiang et al., 2008), peatland (Goldhammer and Blodau, 2008) and desert (Sponseller and Fisher, 2008) ecosystems. For example, in an upper Sonoran Desert ecosystem, $\mathrm{CO}_{2}$ flux increased up to 30 -fold immediately following experimental rewetting, and within $48 \mathrm{~h}$ returned to the rate of gas flux before the event (Sponseller, 2007). In soil moisture manipulations in a Norway spruce plantation, drought and rewetting treatments increased the annual $\mathrm{CO}_{2}$ flux by $51 \%$ compared with a control plot (Borken et al., 1999). Lee et al. (2004) estimated that the increase in $\mathrm{CO}_{2}$ flux in a single intensive storm amounted to a loss of $0.18 \mathrm{tCha}^{-1}$ to the atmosphere, or $5-10 \%$ of the annual net ecosystem production in a mid-latitude forest. These studies have reported increased $\mathrm{CO}_{2}$ flux after rewetting in short-term (ca. 6-24 h) (Table 1, Fig. 3), and relative $\mathrm{CO}_{2}$ flux increases ranging from $40 \%$ to $>9000 \%$ (Table 1 , Fig. 4). The relative $\mathrm{CO}_{2}$ flux increase following rewetting in desert (mean $8425 \%$ ) is higher than those of cropland, forest, grassland, savanna and wetland (100-4400\%) (Table 2). Together, these studies support the hypothesis that rewetting a variety of soil types can have substantial effects on the $C$ balance of terrestrial ecosystems (Borken et al., 1999; Lee et al., 2004; Xu et al., 2004).

Some studies showed no response or small increased $\mathrm{CO}_{2}$ fluxes following rewetting or thawing events and did not substantially affect annual flux rates (Coxson and Parkinson, 1987; Schimel and Clein, 1996; Neilsen et al., 2001; Muhr and Borken, 2009; Muhr et al., 2010). Other studies showed reduced $\mathrm{CO}_{2}$ fluxes during drying periods, but the abruptly increased fluxes following rewetting did not compensate for the reduced rates during the dry period at the seasonal scale (Borken and Matzner, 2009; Joos et al., 2010). In addition, soil $\mathrm{CO}_{2}$ flux could be suppressed during or after rainfall as previously reported: (1) large (10-fold) decreases during light rainfall in arable soils (Rochette et al., 1991), and (2) sharp soil $\mathrm{CO}_{2}$ flux decreases in no-tillage agricultural fields (Ball et al., 1999).

Increased $\mathrm{CO}_{2}$ flux after thawing has been observed in various terrestrial ecosystems, including forest ( $\mathrm{Wu}$ et al., 2010a), alpine tundra (Brooks et al., 1997), and arctic heath (Elberling and Brandt, 2003), and in incubation experiments with soils from cropland (Kurganova et al., 2007), grassland (Wu et al., 2010b), forest (Goldberg et al., 2008), bog (Panikov and Dedysh, 2000), taiga and tundra (Schimel and Clein, 1996), and Antarctica (Zhu et al., 2009). Reported $\mathrm{CO}_{2}$ flux increases after thawing can range up to $5000 \%$ (Table 1, Fig. 4). The relative $\mathrm{CO}_{2}$ flux increase following thawing in tundra $(5530 \%)$ is higher than those of cropland, forest, grassland other ecosystems (150-1630\%; Table 2). Such increases in $\mathrm{CO}_{2}$ flux after seasonal thawing were important to the annual budget of $\mathrm{CO}_{2}$ flux in arable soils (Priemé and Christensen, 2001; Kurganova et al., 2007), but did not affect the annual budget in some natural sites (Coxson and 


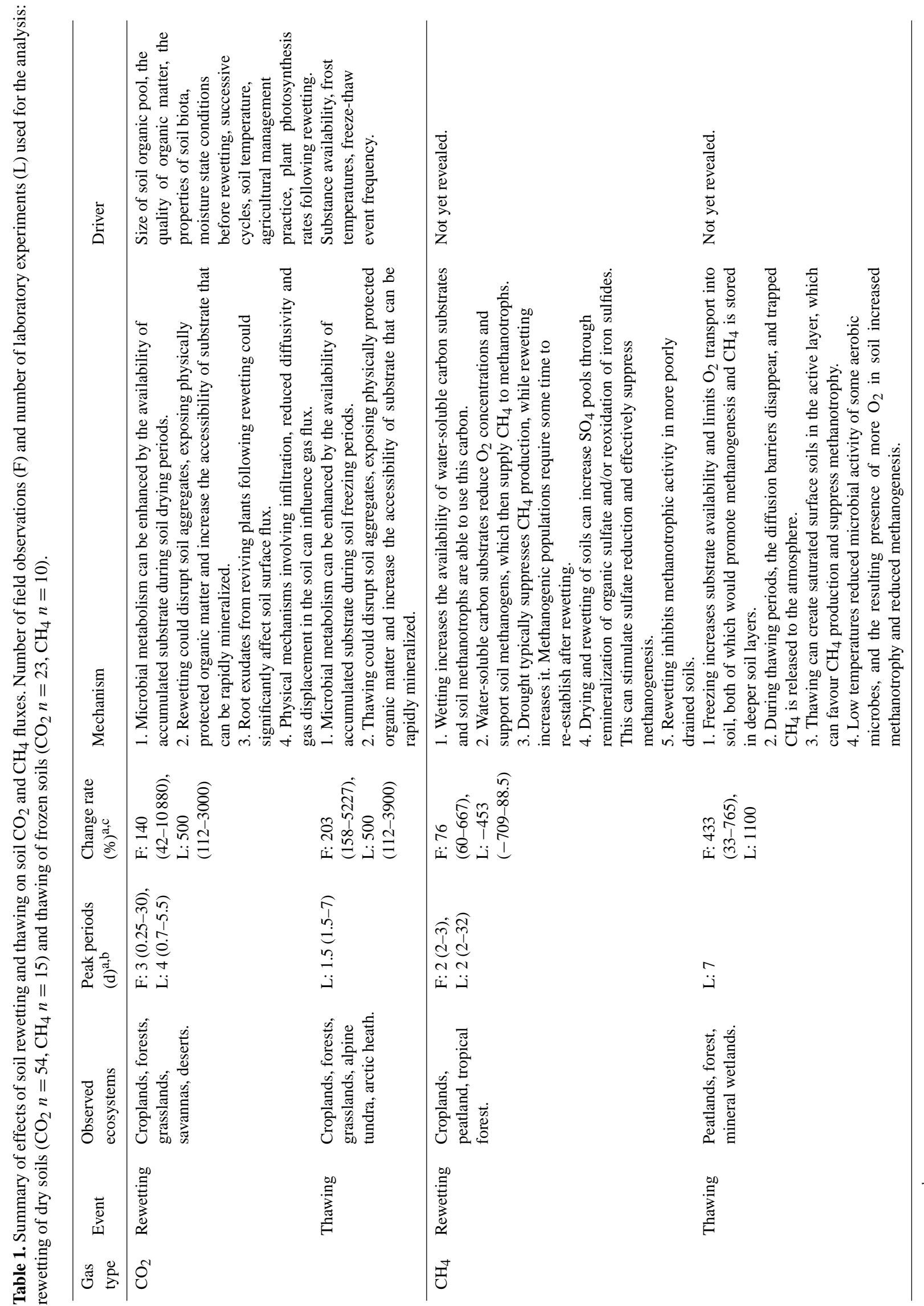


Table 2. Change rate (\%) of soil gas flux following rewetting and thawing events observed in various ecosystems (results from compiled dataset analysis). $\mathrm{F}=$ field observation; $\mathrm{L}=$ laboratory experiment.

\begin{tabular}{|c|c|c|c|c|c|}
\hline \multicolumn{6}{|c|}{ Rewetting event } \\
\hline Ecosystem type & $\mathrm{CO}_{2}$ & $\mathrm{CH}_{4}$ & $\mathrm{~N}_{2} \mathrm{O}$ & NO & $\mathrm{NH}_{3}$ \\
\hline Cropland & $\begin{array}{l}\mathrm{F}: 100 \pm 19(9)^{*} \\
\mathrm{~L}: 1042 \pm 503(4)\end{array}$ & $F: 67 \pm 3(6)$ & $\begin{array}{l}F: 487 \pm 87(3) \\
\text { L: } 68600 \pm 21169(7)\end{array}$ & $\begin{array}{l}F: 1008 \pm 474(5), \\
L: 650 \pm 250(2)\end{array}$ & - \\
\hline Desert & $F: 8425 \pm 4625(2)$ & - & - & $\begin{array}{l}F: 1187 \pm 572(4) \\
L: 2100 \pm 1200(2)\end{array}$ & $\begin{array}{l}F: 561 \pm 182(4), \\
L: 575 \pm 85(4)\end{array}$ \\
\hline Forest & $\begin{array}{l}F: 102 \pm 26(9) \\
L: 800 \pm 530(5)\end{array}$ & L: $-538 \pm 98(3)$ & $\begin{array}{l}F: 9787 \pm 6528(13) \\
L: 85210 \pm 83675(5)\end{array}$ & $\begin{array}{l}\text { F: } 1725 \pm 731(17) \\
\text { L: } 1380 \pm 1002(9)\end{array}$ & - \\
\hline Grassland & $\begin{array}{l}F: 4440 \pm 2510(4) \\
L: 675 \pm 217(5)\end{array}$ & - & $\begin{array}{l}\text { F: } 945 \pm 411(5) \\
\text { L: } 34973 \pm 20571(6)\end{array}$ & $\begin{array}{l}F: 47823 \pm 44885(18) \\
L: 2900 \pm 1806(7)\end{array}$ & - \\
\hline Rice paddy & - & - & $F: 450 \pm 126(3)$ & - & - \\
\hline Sand dune & - & - & - & L: 6900 (1) & - \\
\hline Savanna & $\mathrm{F}: 750 \pm 413(5)$ & - & $F: 1609 \pm 374(7)$ & $\mathrm{F}: 4920 \pm 1835(18)$ & - \\
\hline Wetland & $\mathrm{L}: 130 \pm 18(2)$ & $\mathrm{F}: 471 \pm 112(3)$ & $\begin{array}{l}\text { F: } 1250(1) \\
\text { L: } 8457 \pm 7157(2)\end{array}$ & L: $1700(1)$ & - \\
\hline
\end{tabular}

Thawing event

\begin{tabular}{|c|c|c|c|c|c|}
\hline Ecosystem type & $\mathrm{CO}_{2}$ & $\mathrm{CH}_{4}$ & $\mathrm{~N}_{2} \mathrm{O}$ & $\mathrm{NO}$ & $\mathrm{NH}_{3}$ \\
\hline Arctic heath & $\mathrm{F}: 150(1)$ & - & - & - & - \\
\hline Cropland & L: $918 \pm 418$ (3) & - & $\begin{array}{l}F: 1755 \pm 416(15) \\
L: 62250 \pm 22683(4)\end{array}$ & - & - \\
\hline Forest & $\begin{array}{l}F: 220 \pm 42(3), \\
L: 525 \pm 266(4)\end{array}$ & - & $\begin{array}{l}F: 4176 \pm 1771(9) \\
L: 619 \pm 173(5)\end{array}$ & - & - \\
\hline Grassland & L: $752 \pm 262$ (4) & F: $33(1)$ & $\begin{array}{l}F: 836 \pm 33(3) \\
\text { L: } 35052 \pm 20585(6)\end{array}$ & $\mathrm{L}: 500(2)$ & - \\
\hline Sand dune & L: 900 (1) & - & L: 100 (1) & $\mathrm{L}: 40$ (1) & - \\
\hline Tundra & F: 5227 (1) & $F: 433 \pm 67$ (2) & F: $748(1)$ & - & - \\
\hline Wetland & $\mathrm{L}: 1631 \pm 1519(2)$ & $\begin{array}{l}\text { F: } 538 \pm 227(3), \\
\text { L: } 1100(1)\end{array}$ & $\mathrm{L}: 3271 \pm 2581$ & L: 200 (1) & - \\
\hline
\end{tabular}

* Mean \pm standard error (number of samples); “"” no data.

Parkinson, 1987; Schimel and Clein, 1996; Neilsen et al., 2001). However, we caution that most of these studies lack the high temporal sampling resolution necessary to capture the full dynamic of the pulse (Groffman et al., 2006; Muhr et al., 2009, Vargas et al., 2011), as shown in Fig. 2.

\subsubsection{Methane}

Net $\mathrm{CH}_{4}$ flux is the result of the balance between methanogenesis (microbial production under anaerobic conditions) and methanotrophy (microbial consumption) (Dutaur and Verchot, 2007). Methanogenesis occurs via the anaerobic degradation of organic matter by methanogenic archaea within the archaeal phylum Euryarchaeota (Thauer, 1998). Methanotrophy occurs by methanotrophs metabolizing $\mathrm{CH}_{4}$ as their source of carbon and energy (Hanson and Hanson, 1996). In anoxic soils, emergent vegetation also influences $\mathrm{CH}_{4}$ flux to the atmosphere, as plants enable oxygen transport to the rhizosphere through aerenchymateous tissue and through the production of labile substrates via root exudation
(Joabsson et al., 1999). Methane also can be stored in soils and consequently released to the atmosphere during changes in pressure such as with freezing (Mastepanov et al., 2008). Plant mediated release likely reduces $\mathrm{CH}_{4}$ storage in soils and thus could reduce episodic releases of $\mathrm{CH}_{4}$ (Chanton, 2005; Tagesson et al., 2012), though other studies have found no relationship between vascular plant abundance and ebullition (Coulthard et al., 2009; Green and Baird, 2012). Our database contains 25 studies that measured $\mathrm{CH}_{4}$ and are equivalent to $\sim 7 \%$ of all studies. This shows that $\mathrm{CH}_{4}$ is one of the soil gases that have received the least attention for studying the effects of rewetting and thawing of soils.

The reported effects of rewetting and thawing on $\mathrm{CH}_{4}$ fluxes were variable within our database. Rewetting reduced $\mathrm{CH}_{4}$ consumption or increased $\mathrm{CH}_{4}$ production in arable land (Syamsul Arif et al., 1996; Kessavalou et al., 1998; Hergoualc'h et al., 2008), peatlands (Kettunen et al., 1996; Blodau and Moore, 2003; Dinsmore et al., 2009), and tropical forests (Silver et al., 1999). In a wheat-fallow 


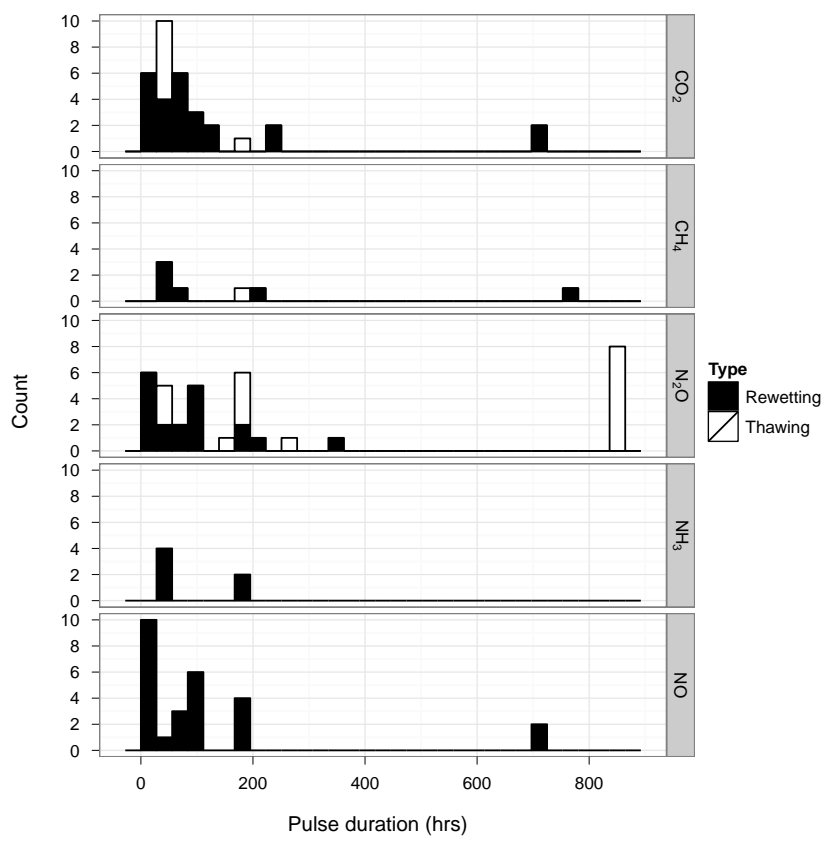

Fig. 3. Histograms of the duration of increased flux of soil gas $\mathrm{CO}_{2}$, $\mathrm{CH}_{4}, \mathrm{~N}_{2} \mathrm{O}$, NO and $\mathrm{NH}_{3}$ following soil rewetting and thawing in field and laboratory experiments.

cropping system, $\mathrm{CH}_{4}$ consumption declined by about $60 \%$ for 3-14 d after rewetting (Kessavalou et al., 1998). In peatland, a pulse of $\mathrm{CH}_{4}$ was observed after water table drawdown (Moore and Knowles, 1990; Shurpali et al., 1993), and substantial pulses of $\mathrm{CH}_{4}$ fluxes were produced with both drainage (700 $\mu \mathrm{g} \mathrm{m}^{-2} \mathrm{~h}^{-1}$ above the pre-change mean) and rewetting (over $160 \mu \mathrm{g} \mathrm{m}^{-2} \mathrm{~h}^{-1}$ above the value of prior to rewetting) within 1-2 days in a mesocosm study (Dinsmore et al., 2009). In contrast, other studies have reported that rewetting increased $\mathrm{CH}_{4}$ consumption, or reduced $\mathrm{CH}_{4}$ production, both in the field (Davidson et al., 2004, 2008; Borken et al., 2006; Fiedler et al., 2008) and laboratory (Czepiel et al., 1995; West and Schmidt, 1998; Estop-Aragonés and Blodau, 2012). In incubation experiments with alpine soil, $\mathrm{CH}_{4}$ oxidation increased significantly from $11 \mathrm{pmol} \mathrm{CH}_{4}$ (g dry weight) ${ }^{-1} \mathrm{~h}^{-1}$ to -67.0 $-29.5 \mathrm{pmol} \mathrm{CH}_{4}$ (g dry weight $)^{-1} \mathrm{~h}^{-1} 9$ days after rewetting (West and Schmidt, 1998). Enhanced $\mathrm{CH}_{4}$ oxidation was promoted after rewetting for days to weeks in peatland (Öquist and Sundh, 1998; Kettunen et al., 1999; Goldhammer and Blodau, 2008) and rice field (Ratering and Conrad, 1998). However, in an in situ water table drawdown experiment, $\mathrm{CH}_{4}$ production declined in hummocks but stayed constant in hollows relative to control plots, suggesting a strong role of microtopography in the effects of rewetting on $\mathrm{CH}_{4}$ fluxes (Strack and Waddington, 2007).

Seasonal thawing of soils increased $\mathrm{CH}_{4}$ flux in a peatland (Tokida et al., 2007), forest (Kim and Tanaka, 2003), and wetlands (Friborg et al., 1997; Song et al., 2006; Ding

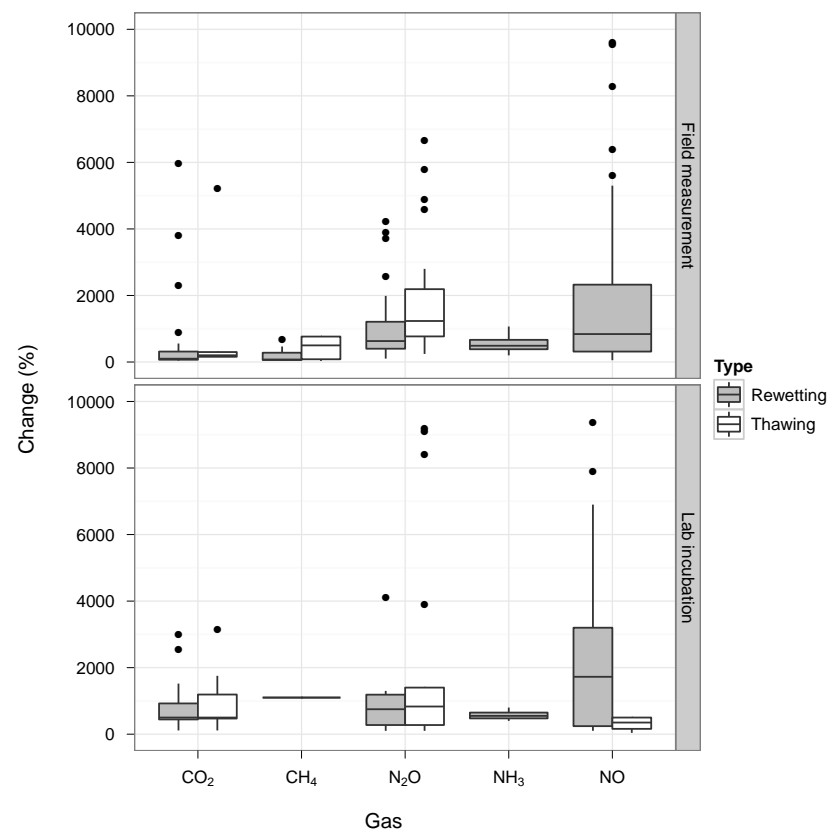

Fig. 4. Change rate (\%) of soil gas $\mathrm{CO}_{2}, \mathrm{CH}_{4}, \mathrm{~N}_{2} \mathrm{O}$, $\mathrm{NO}$ and $\mathrm{NH}_{3}$ fluxes following soil rewetting and thawing in field and laboratory experiments. Top and bottom of box are 25 th and 75 th percentiles; whiskers extend to $1.5 \times$ interquartile range.

and Cai, 2007; Yu et al., 2007). In a subarctic peatland, $\mathrm{CH}_{4}$ flux increased from $2.6 \mathrm{mg} \mathrm{m}^{-2} \mathrm{~d}^{-1}$ to $22.5 \mathrm{mg} \mathrm{m}^{-2} \mathrm{~d}^{-1}$ during thawing, with the latter rate equivalent to approximately $25 \%$ of the mid-summer flux (Friborg et al., 1997). A few studies have also shown enhanced $\mathrm{CH}_{4}$ consumption during seasonal thawing periods (Ding and Cai, 2007; Wu et al., 2010b). In addition to affecting rates of $\mathrm{CH}_{4}$ production and oxidation, seasonal soil thaw also may affect $\mathrm{CH}_{4}$ transport mechanisms (Friborg et al., 1997; Kim and Tanaka, 2003; Tokida et al., 2007). For example, surface seasonal thawing in a bog appeared to trigger ebullition events, with flux up to $25.3 \mathrm{mg} \mathrm{CH}_{4} \mathrm{~m}^{-2} \mathrm{~h}^{-1}$ (Tokida et al., 2007). In Alaskan boreal forest soils damaged by fire, $\mathrm{CH}_{4}$ flux increased 7-142\% during seasonal thawing (Kim and Tanaka, 2003). Longerterm increases in an active layer depth with permafrost thaw also tend to increase $\mathrm{CH}_{4}$ flux in high latitude wetlands and lakes (Turetsky et al., 2002; Christensen et al., 2004; Walter et al., 2006; Anisimov, 2007), although these processes are not the focus of this review. In summary, studies report a large uncertainty in $\mathrm{CH}_{4}$ responses after rewetting and thawing, but there are much smaller responses in magnitude and fewer observations compared with other gases (Table 1, Fig. 3).

\subsubsection{Nitrous oxide}

Three main processes produce $\mathrm{N}_{2} \mathrm{O}$ in soils: (1) nitrification, the stepwise oxidation of $\mathrm{NH}_{3}$ to nitrite $\left(\mathrm{NO}_{2}^{-}\right)$and to nitrate 
$\left(\mathrm{NO}_{3}^{-}\right.$) (Kowalchuk and Stephen, 2001); (2) denitrification, the stepwise reduction of $\mathrm{NO}_{3}^{-}$to $\mathrm{NO}_{2}^{-}, \mathrm{NO}, \mathrm{N}_{2} \mathrm{O}$ and ultimately $\mathrm{N}_{2}$, where facultative anaerobic bacteria use $\mathrm{NO}_{3}^{-}$ as an electron acceptor in the respiration of organic material under low oxygen $\left(\mathrm{O}_{2}\right)$ conditions (Knowles, 1982); and (3) nitrifier denitrification, which is carried out by autotrophic $\mathrm{NH}_{3}$-oxidizing bacteria and the pathway whereby $\mathrm{NH}_{3}$ is oxidized to nitrite $\mathrm{NO}_{2}^{-}$, followed by the reduction of $\mathrm{NO}_{2}^{-}$to nitric oxide $\mathrm{NO}, \mathrm{N}_{2} \mathrm{O}$ and molecular nitrogen $\left(\mathrm{N}_{2}\right)$ (Wrage et al., 2001). Our database contains 165 studies that measured $\mathrm{N}_{2} \mathrm{O}$ and are equivalent to $\sim 40 \%$ of all studies. This shows that $\mathrm{N}_{2} \mathrm{O}$ is the soil gas that has received the most attention for studying the effects of rewetting and thawing of soils.

Field studies have observed increased soil $\mathrm{N}_{2} \mathrm{O}$ flux following wetting in cropland (Barton et al., 2008), grazed pasture (Kim et al., 2010a), tropical forest (Butterbach-Bahl et al., 2004), grassland (Hao et al., 1988), savannah (Martin et al., 2003), and fen (Goldberg et al., 2010a). Laboratory incubation experiments with cropland (Beare et al., 2009), forest (Dick et al., 2001), grassland (Yao et al., 2010), and peatland soils (Dinsmore et al., 2009) have yielded similar results of increased $\mathrm{N}_{2} \mathrm{O}$ flux after rewetting. In tropical soils in Costa Rica, $\mathrm{N}_{2} \mathrm{O}$ flux pulses began within 30 min, peaking no later than $8 \mathrm{~h}$ after rewetting, and $25 \mathrm{~g} \mathrm{~N}_{2} \mathrm{O}-\mathrm{N} \mathrm{ha}^{-1}$ was emitted for three simulated rain events over a 22-day period (control emitted $14 \mathrm{~g} \mathrm{~N}_{2} \mathrm{O}-\mathrm{N} \mathrm{ha}^{-1}$ ), and one episodic $\mathrm{N}_{2} \mathrm{O}$ production event driven by one moderate rain accounted for $15-90 \%$ of the total weekly production (Nobre et al., 2001). These studies have observed increased soil $\mathrm{N}_{2} \mathrm{O}$ flux following rewetting in short-term $(\sim 12 \mathrm{~h}-15 \mathrm{~d}$; Table 3, Fig. 3), and an increase of $\mathrm{N}_{2} \mathrm{O}$ flux up to $80000 \%$ with respect to the background conditions (Table 3, Fig. 4). Increases of forest $\mathrm{N}_{2} \mathrm{O}$ fluxes following rewetting $(9790 \%)$ are higher than those of cropland, grassland other ecosystems (450-1250\%) (Table 2). Noteworthy, our dataset reveals that even a single wetting event can affect annual $\mathrm{N}_{2} \mathrm{O}$ flux between $2 \%$ and $50 \%$ (Nobre et al., 2001; Barton et al., 2008; Goldberg et al., 2010a).

Increased soil $\mathrm{N}_{2} \mathrm{O}$ flux following thawing has been observed in cropland (Rochette et al., 2010), grassland (Virkajärvi et al., 2010), forest (Maljanen et al., 2010), marsh (Yu et al., 2007), alpine meadow (Hu et al., 2010), and alpine tundra (Brooks et al., 1997). Laboratory incubation experiments showing similar results have been performed with agricultural (Kurganova et al., 2004), grassland (Yao et al., 2010), forest (Goldberg et al., 2008), permafrost (Elberling et al., 2010), and coastal Antarctica soils (Zhu et al., 2009). Episodic $\mathrm{N}_{2} \mathrm{O}$ peak fluxes of up to $750 \mu \mathrm{g} \mathrm{N}_{2} \mathrm{O}-\mathrm{N} \mathrm{m}^{-2} \mathrm{~h}^{-1}$ (background levels of under $50 \mu \mathrm{g} \mathrm{N}_{2} \mathrm{O}-\mathrm{N} \mathrm{m}^{-2} \mathrm{~h}^{-1}$ ) were measured after freeze-thaw in arable field (Dörsch et al., 2004). Such increases usually occur when soil temperatures are close to $0^{\circ} \mathrm{C}$ (Christensen and Tiedje, 1990; Chen et al., 1995; Müller et al., 2003). Studies examining the thawing effect on $\mathrm{N}_{2} \mathrm{O}$ flux have reported 6 to $35 \mathrm{~d}$ response following rewetting (Table 3) and $\mathrm{N}_{2} \mathrm{O}$ fluxes increase up to $17000 \%$ (Table 3, Fig. 4). Increase of $\mathrm{N}_{2} \mathrm{O}$ flux following thawing in forest $(4180 \%)$ is higher than those of cropland, grassland and other ecosystems (750-1760\%; Table 2). Thaw-induced $\mathrm{N}_{2} \mathrm{O}$ fluxes constituted a major component of annual $\mathrm{N}_{2} \mathrm{O}$ fluxes from arable field (Regina et al., 2004; Johnson et al., 2010), temperate grassland (Kammann et al., 1998; Müller et al., 2002), steppe (Holst et al., 2008; Wolf et al., 2010), wetland (Yu et al., 2007) and forest ecosystems (Papen and Butterbach-Bahl, 1999; Wu et al., 2010a; Guckland et al., 2010), with contributions exceeding $50 \%$ of the annual budget in some years.

In contrast, some studies showed no response or small increased $\mathrm{N}_{2} \mathrm{O}$ fluxes following rewetting or thawing events that did not substantially affect annual flux rates (GarciaMontiel et al., 2003; Neill et al., 2005; Borken and Matzner, 2009). Some studies showed reduced $\mathrm{N}_{2} \mathrm{O}$ fluxes during drying periods, but the abruptly increased fluxes following rewetting did not compensate for the reduced or nil uptake rates during the dry period at the seasonal scale (Borken and Matzner, 2009; Goldberg and Gebauer, 2009).

\subsubsection{Nitric oxide}

Nitric oxide can be produced from: (1) nitrification (Kowalchuk and Stephen, 2001); (2) denitrification (Knowles, 1982); and (3) nitrifier denitrification (Wrage et al., 2001), as described in Sect. 3.1.3. Our database contains 92 studies that measured $\mathrm{NO}$ and are equivalent to $\sim 27 \%$ of all studies. This shows that NO is the soil gas that has received the second most attention for studying the effects of rewetting and thawing of soils.

Increases in soil NO flux following rewetting have been reported in various terrestrial ecosystems, including cropland (Guenzi et al., 1994), grazing pasture (Hutchinson and Brams, 1992), forest (Wu et al., 2010a), grassland (Hartley and Schlesinger, 2000), savanna (Martin et al., 2003), and desert (McCalley and Sparks, 2008). Laboratory incubations with grassland soil (Yao et al., 2010), grazing pasture soil (Hutchinson et al., 1993), forest soil (Dick et al., 2006), and desert soil (McCalley and Sparks, 2008) have reported similar results of increased NO flux after rewetting. Rewetting studies have commonly reported a short-term increase in NO fluxes (ca. 1-3 d; Table 3, Fig. 3), and the rate of increase of NO flux ranged from $40 \%$ to more than $800000 \%$ (Table 3, Fig. 4). Increase of NO flux following rewetting in grassland $(47800 \%)$ is higher than those of cropland, forest and other ecosystems (1000-4900\%; Table 2). Some studies indicate that even a single rewetting event could substantially affect the annual flux rates of NO (Davidson et al., 1991; Yienger and Levy, 1995; Kitzler et al., 2006), and rewetting events could be important for regional fluxes (Harris et al., 1996; Ghude et al., 2010).

Increased soil NO fluxes following thawing have been observed only in a field study (Laville et al., 2011) and in a 





laboratory incubation study (Yao et al., 2010). In a French crop field, NO fluxes following thawing increased up to $10 \mathrm{ng} \mathrm{N} \mathrm{m}^{-2} \mathrm{~s}^{-1}$ and decreased to pre-event values within $24 \mathrm{~h}$, while the flux average was 1.7 to $2.3 \mathrm{ng} \mathrm{N} \mathrm{m}^{-2} \mathrm{~s}^{-1}$ in two years (Laville et al., 2011). Incubation with the soils of steppe, mountain meadow, sand dune, and marshland in Inner Mongolia showed that NO fluxes were $0.5-8.0 \mu \mathrm{g} \mathrm{N} \mathrm{m}^{-2} \mathrm{~h}^{-1}$ at $-10^{\circ} \mathrm{C}$ and they increased to around $30 \mu \mathrm{g} \mathrm{N} \mathrm{m}{ }^{-2} \mathrm{~h}^{-1}$ following thawing (at $5^{\circ} \mathrm{C}$ ) (Yao et al., 2010).

\subsubsection{Ammonia}

Soil $\mathrm{NH}_{3}$ is primarily produced when ammonium ions $\left(\mathrm{NH}_{4}^{+}\right)$dissociate into gaseous $\mathrm{NH}_{3}$ under alkaline conditions, and $\mathrm{NH}_{3}$ flux is sensitive to soil conditions that influence $\mathrm{NH}_{4}^{+}$concentrations (Schlesinger and Peterjohn, 1991; McCalley and Sparks, 2008). Our database contains only 8 studies that measured $\mathrm{NH}_{3}$. This shows that $\mathrm{NH}_{3}$ is the soil gas that has received the least attention for studying the effects of rewetting and thawing of soils.

Increases in soil $\mathrm{NH}_{3}$ flux following rewetting have been observed mainly in deserts (Schlesinger and Peterjohn, 1991; McCalley and Sparks, 2008). In the Chihuahuan Desert, USA, simulated rainfall increased $\mathrm{NH}_{3}$ fluxes from $15 \mu \mathrm{g} \mathrm{N} \mathrm{m}{ }^{-2} \mathrm{~d}^{-1}$ to $95 \mu \mathrm{g} \mathrm{N} \mathrm{m}^{-2} \mathrm{~d}^{-1}$ within $24 \mathrm{~h}$ and the fluxes declined as the soils dried during the next 7 days (Schlesinger and Peterjohn, 1991). Similarly, increased $\mathrm{NH}_{3}$ fluxes following a natural rainfall were 5-10 times higher than pre-rain fluxes in the Mojave Desert, USA (McCalley and Sparks, 2008). Studies examining how rewetting affects $\mathrm{NH}_{3}$ flux have commonly reported $7 \mathrm{~d}$ response following rewetting (Table 3), with the rate of $\mathrm{NH}_{3}$ flux increase ranging from $200 \%$ to $>1000 \%$ (Table 3, Fig. 4). To our knowledge, no study has looked at changes in soil $\mathrm{NH}_{3}$ flux following thawing.

\subsection{Mechanisms for soil gas flux response to rewetting and thawing}

\subsubsection{Common mechanisms among soil gas fluxes}

Two broad mechanisms responsible for changed soil gas flux following rewetting and thawing have been commonly hypothesized: (1) enhanced microbial metabolism by substrate supply, and (2) physical mechanisms.

First, microbial metabolism can be enhanced by the availability of accumulated substrates during soil drying and frozen periods that become available as solutes in water after rewetting or thawing of soils. A large proportion of microorganisms, fine roots and mycorrhiza die during drought and frozen conditions (Clein and Schimel, 1994; Teepe et al., 2001; Wolf et al., 2010, Supplementary information); these dead cells tend to have low C:N ratios and could rapidly decompose during rewetting (Kieft et al., 1987; Van Gestel et al., 1993) and thawing (Priemé and Christensen, 2001;
Yergeau and Kowalchuk, 2008). Microorganisms accumulate high concentrations of solutes (osmolytes) to retain water inside the cell during drought conditions (Harris, 1981), which rapidly decompose on rewetting (Fierer and Schimel, 2003; Schimel et al., 2007). Dry-wet and freeze-thaw could disrupt soil aggregates, exposing physically protected organic matter and increase the accessibility of substrate that can be rapidly mineralized (Groffman and Tiedje, 1988; Appel, 1998; Pesaro et al., 2003; Grogan et al., 2004). Furthermore, root exudates from reviving plants following rewetting could significantly affect soil surface flux (Crow and Wieder, 2005; Curiel Yuste et al., 2007).

Second, physical mechanisms that can influence gas flux include infiltration, reduced diffusivity, and gas displacement in the soil (Jensen et al., 1996; Huxman et al., 2004). For example, the infiltration of rainwater may displace $\mathrm{CO}_{2}$ that accumulates in soil pore spaces during dry periods (Huxman et al., 2004; Marañón-Jiménez et al., 2011). Changing atmospheric pressure (e.g., under windy conditions) can also create Venturi and other pressure effects that suppress or enhance soil-to-air gas fluxes (Xu et al., 2006). In the following sections, we discuss the characteristic mechanisms responsible for changes in fluxes for each soil gas.

\subsubsection{Carbon dioxide}

The mechanisms responsible for increased $\mathrm{CO}_{2}$ flux following rewetting and thawing have been commonly hypothesized as belonging to two categories: (1) enhanced microbial metabolism, and (2) the physical mechanisms described above (Sect. 3.2.1). Importantly, the relative contribution of autotrophic or heterotrophic activity to changes in $\mathrm{CO}_{2}$ fluxes following rewetting and thawing is still poorly understood. In a Mediterranean dehesa, autotrophic activity was dominant during drought periods but heterotrophic activity became dominant for $\mathrm{CO}_{2}$ fluxes following rewetting events (Casals et al., 2011).

Possible explanations for the reduced soil $\mathrm{CO}_{2}$ flux rates during or after rainfall are: (1) increased accumulation of rain water in the soil pore space that reduces soil $\mathrm{CO}_{2}$ diffusivity rates (Rochette et al., 1991; Šimùnek and Suarez, 1993), and (2) restriction of the soil macro-porosity by rainfall that reduces soil air-filled pore space, enhances anaerobiosis and reduces aerobic respiration (Linn and Doran, 1984; Ball et al., 1999; Davidson et al., 2000).

\subsubsection{Methane}

In general, $\mathrm{CH}_{4}$ production rates are controlled by the availability of suitable substrates, alternative electron acceptors for competing redox reactions (i.e., sulfate reduction), the nutritional status of the ecosystem (i.e., bog versus fen), water table position or soil moisture content, temperature, and soil salinity (Thauer, 1998; Hanson and Hanson, 1996; Dutaur and Verchot, 2007). 
The mechanisms underlying changes in $\mathrm{CH}_{4}$ flux following rewetting and thawing are complex because they involve the response of both methanogenesis and methanotrophy to changes in availability of substrates, soil environment, particularly soil moisture, and availability of electron donors and acceptors that determine the redox status of soil. Additionally, changes to the physical soil environment can indirectly influence $\mathrm{CH}_{4}$ flux by affecting vegetation composition and abundance as well as the tendency for soils to store bubbles. Rewetting can increase the availability of water-soluble C substrates (Zsolnay and Görlitz, 1994; Stark and Firestone, 1995; Sect. 3.2.1) that are being used by soil methanotrophs (Whittenbury et al., 1970). In unfrozen soils, there was no correlation between soil temperature and $\mathrm{CH}_{4}$ consumption, suggesting strong substrate limitation on methanotrophs (Borken et al., 2006). Borken et al. (2006) also found that methanotrophs were stressed when water contents were below $0.15 \mathrm{~g} \mathrm{~cm}^{-3}$ (in the A horizon), thus rewetting could alleviate osmotic stress and promote the growth and activity of soil methanotrophs (Schnell and King, 1994; West and Schmidt, 1998). While several studies have shown that experimental drought increased $\mathrm{CH}_{4}$ consumption rates (cf. Borken et al., 2006; Davidson et al., 2008), Fiedler et al. (2008) found no evidence of increased methanotrophy in response to natural drought in forest soils. Methanotrophs responded quickly to water table manipulations in peat soil (Blodau and Moore, 2003). Rewetting also can inhibit methanotrophic activity in more poorly drained soils, for example, if oxygen diffusion becomes limiting (Striegl, 1993). Because methanogenesis requires anaerobic soil conditions, drought typically suppresses $\mathrm{CH}_{4}$ production, while rewetting increases it. Methanogenic populations require some time to re-establish after rewetting (Fetzer et al., 1993).

In addition to environmental controls, both methanotrophy and methanogenesis are sensitive to interactions and competition with other microbial redox processes. Drying and rewetting of soils can increase $\mathrm{SO}_{4}$ pools through remineralization of organic sulfate and/or reoxidation of iron sulfides. This can stimulate sulfate reduction and effectively suppress methanogenesis (cf. Blodau and Moore, 2003). In thick organic soils, this is more likely to occur in surface layers that experience fluctuating water tables than in more saturated, deeper peat layers (Goldhammer and Blodau, 2008).

Freezing increases substrate availability (Sect. 3.2.1) and limits diffusive transport of gases (including $\mathrm{O}_{2}$ ) into and out of soil, which could promote methanogenesis and the storage of $\mathrm{CH}_{4}$ in deeper soil layers (Yu et al., 2007). Also, $\mathrm{CH}_{4}$ typically accumulates subsurface in snow or ice covered ecosystems. During thawing periods, the diffusion barriers disappear and trapped $\mathrm{CH}_{4}$ is released to the atmosphere (Friborg et al., 1997; Yu et al., 2007). Methane emissions were independent of temperature $<0{ }^{\circ} \mathrm{C}$ (Friborg et al., 1997; Yu et al., 2007), suggesting that biological activity is not the dominant control on soil $\mathrm{CH}_{4}$ flux during early soil thaw. As the soil active layer becomes thicker, soil $\mathrm{CH}_{4}$ fluxes is driven by soil aeration and redox controls on methanotrophy and methanogenesis, as described above for rewetting. In particular, due to poor drainage of melting snow and seasonal ice, thawing can create saturated surface soils in the active layer, which can favour $\mathrm{CH}_{4}$ production (Thauer, 1998) and suppress methanotrophy. In contrast, Ding and Cai (2007) found that low temperatures reduced microbial activity of some aerobic microbes, and the resulting presence of more $\mathrm{O}_{2}$ in soil increased methanotrophy and reduced methanogenesis. Overall, to our knowledge the mechanisms responsible for the various response of $\mathrm{CH}_{4}$ to rewetting and thawing have not been clearly explored and further research is needed to identify the mechanisms controlling the response after rewetting and thawing across ecosystems.

\subsubsection{Nitrous oxide}

The mechanisms responsible for increased $\mathrm{N}_{2} \mathrm{O}$ flux following rewetting have been commonly hypothesized as belonging to two categories: (1) enhanced microbial metabolism, and (2) the physical mechanisms described above (Sect. 3.2.1). Similarly, the enhanced substrate supply described above (Sect. 3.2.1) and physical mechanisms have been hypothesized as responsible for increased $\mathrm{N}_{2} \mathrm{O}$ fluxes following thawing. The hypothesized physical mechanisms for increased $\mathrm{N}_{2} \mathrm{O}$ fluxes following thawing are: first, anaerobic water-saturated topsoil conditions are created during thawing by reduced drainage of melting ice and snow in the frozen subsoil, and these conditions are known to increase $\mathrm{N}_{2} \mathrm{O}$ fluxes (Li et al., 2000; de Bruijn et al., 2009). Second, ice layers prevent $\mathrm{N}_{2} \mathrm{O}$ exchange between topsoil and atmosphere and during thawing periods, the diffusion barriers disappear, and the trapped $\mathrm{N}_{2} \mathrm{O}$ is released into the atmosphere within a few days (Goldberg et al., 2010b; Virkajärvi et al., 2010). Increased $\mathrm{N}_{2} \mathrm{O}$ fluxes following thawing may be caused by the combination of these two mechanisms (Koponen et al., 2006; de Bruijn et al., 2009).

Enhanced nutrient supply from soil freezing has been accepted as one of the mechanisms to explain abruptly increased $\mathrm{N}_{2} \mathrm{O}$ fluxes. However, Hentschel et al. (2009) found that moderate soil freezing did not affect solute losses of $\mathrm{N}, \mathrm{DOC}$, and mineral ions from temperate forest soils, and argued that their results did not support the hypothesis that $\mathrm{N}_{2} \mathrm{O}$ peak fluxes are caused by the enhanced nutrient supply from soil freezing (Goldberg et al., 2010b). While it has been argued that $\mathrm{N}_{2} \mathrm{O}$ peak flux at spring thaw was mostly produced in the surface layer (Müller et al., 2002; Furon et al., 2008; Wagner-Riddle et al., 2008), Goldberg et al. (2010b) found that released $\mathrm{N}_{2} \mathrm{O}$ in soil thawing was due to a slow release of subsoil $\mathrm{N}_{2} \mathrm{O}$ and a delayed activation of $\mathrm{N}_{2} \mathrm{O}$ reductase in the topsoil after soil frost due to low soil temperatures. 
The relative contribution of specific microbial processes (e.g., nitrification, denitrification and nitrifier denitrification) to changes in $\mathrm{N}_{2} \mathrm{O}$ fluxes following rewetting and thawing is still poorly understood, although several studies have found denitrification to be a major contribution process in $\mathrm{N}_{2} \mathrm{O}$ fluxes following rewetting (Groffman and Tiedje, 1988; Priemé and Christensen, 2001) and thawing (Mørkved et al., 2006; Sharma et al., 2006; Wagner-Riddle et al., 2008).

\subsubsection{Nitric oxide}

The mechanisms responsible for increased NO fluxes following rewetting have been commonly hypothesized as belonging to the two categories: (1) enhanced microbial metabolism by substrate supply, and (2) physical mechanisms described above (Sect. 3.2.1). Several studies found that nitrification is the dominant source of increased NO flux following wetting of dry soils (Davidson, 1992a; Davidson et al., 1993; Hutchinson et al., 1993).

\subsubsection{Ammonia}

The mechanisms responsible for the response of $\mathrm{NH}_{3}$ to rewetting have not been explored to our knowledge. We hypothesized that increase in $\mathrm{NH}_{4}^{+}$caused by enhanced $\mathrm{N}$ mineralization following rewetting (Tomoaki Morishita, unpublished data) and rewetting promotes reaction between $\mathrm{NH}_{4}^{+}$ and $\mathrm{OH}^{-}$, without biota (James Raich, unpublished data) results in increased $\mathrm{NH}_{3}$ flux.

\subsection{Drivers for soil gas flux response to rewetting and thawing}

\subsubsection{Carbon dioxide}

The magnitude of $\mathrm{CO}_{2}$ flux increases following rewetting may depend on: (1) the size of the soil organic pool; (2) the quality of organic matter, determined by its age, origin, and the extent to which these substrates are protected from microbial attack by adsorption to clay surfaces and inclusion in micro-aggregates; and (3) the properties of soil biota (Van Gestel et al., 1993). Soil moisture conditions before rewetting also influence the response (Orchard and Cook, 1983; Cable et al., 2008; Harms and Grimm, 2012), as can the length and severity of drought periods (Unger et al., 2010), and rain pulse size (Sponseller, 2007; Chen et al., 2009). Based on our literature review, we identified the existence of a threshold in soil moisture at $12-20 \%$ gravimetric moisture content, below which a substantial increase in soil $\mathrm{CO}_{2}$ flux after rewetting is typically observed (Davidson et al., 1998; Xu and Qi, 2001; Rey et al., 2002; Yuste et al., 2003; Dilustro et al., 2005; Cable et al., 2008; Chou et al., 2008; Kim et al., 2010b; Misson et al., 2010).

The effects of rewetting may decline with successive drying and rewetting cycles, possibly as a result of a limited pool of labile substrates that have built up over time or during the dry season (Schimel and Mikan, 2005; Goldberg et al., 2008). Importantly, Fernández et al. (2006) suggested that substrate availability, rather than soil moisture, influenced the duration of the $\mathrm{CO}_{2}$ pulse in response to rain events, while Vargas et al. (2010b) noted that $\mathrm{CO}_{2}$ flux pulses may be driven not only by labile substrate availability, but also by plant photosynthesis rates following the rain event. It can be difficult to separate the often-confounded factors controlling $\mathrm{CO}_{2}$ flux pulses, requiring measurement of microbial communities, isotopic composition, and/or precise flux timing. For example, Unger et al. (2012) used $\delta^{13} \mathrm{C}$ to separate out the effects of soil moisture versus substrate availability in an oak woodland. In addition, management practice (mowing or tillage) (Steenwerth et al., 2010), vegetation type (Shi et al., 2011) and high soil temperatures (Jager and Bruins, 1975; Borken et al., 1999) could influence the magnitude of the response of soil $\mathrm{CO}_{2}$ flux following rewetting of dry soils.

The magnitude of increased $\mathrm{CO}_{2}$ flux following thawing is controlled by characteristics of thawing events. For example, frozen soils in colder temperatures show greater increase of $\mathrm{CO}_{2}$ flux following thawing, possibly as a result of higher amounts of substrate accumulated in colder temperatures (Matzner and Borken, 2008; Goldberg et al., 2008). Another known factor is freeze-thaw cycle frequency, where the largest $\mathrm{CO}_{2}$ flux increase commonly occurs in the first thawing event (among repeated freezing-thawing cycles), with the effects declining in following cycles (Priemé and Christensen, 2001; Kurganova and Tipe, 2003; Goldberg et al., 2008) due to limited pool of labile substrates that have built up over time (Priemé and Christensen, 2001; Goldberg et al., 2008).

\subsubsection{Methane}

To our knowledge, the drivers responsible for the magnitude of change in soil $\mathrm{CH}_{4}$ flux following rewetting and thawing have not been clearly explored. We recommend that further research is needed to identify the drivers controlling the response after rewetting and thawing across ecosystems. The lack of understanding about drivers from $\mathrm{CH}_{4}$ fluxes is reflected in the low percentage of studies $(\sim 7 \%)$ in our database.

\subsubsection{Nitrous oxide}

The magnitude of increased $\mathrm{N}_{2} \mathrm{O}$ flux caused by the wetting of dry soils varies, depending on the labile $\mathrm{N}$ soil pool (Van Gestel et al., 1993; Schaeffer et al., 2003), soil texture (Appel, 1998; Austin et al., 2004), soil water content (Appel, 1998), the size of the rewetting pulse (Ruser et al., 2006; Yanai et al., 2007), length of drought (van Haren et al., 2005), and soil compaction (Uchida et al., 2008; Beare et al., 2009). A significant relationship between the organic $\mathrm{N}$ extracted from dried soil samples and the magnitude of $\mathrm{N}_{2} \mathrm{O}$ flushes following soil drying-rewetting has been observed (Appel, 
1998). Field and laboratory studies with arid and semiarid soils, fine-textured soils with higher water-holding capacity and labile $\mathrm{C}$ and $\mathrm{N}$ pools compared with coarse-textured soils, showed a greater flush of $\mathrm{N}_{2} \mathrm{O}$ flux following rewetting (Austin et al., 2004). In an incubation experiment with soils from a potato field, the amount of increase in $\mathrm{N}_{2} \mathrm{O}$ flux following rewetting was enhanced with the amount of water added (Ruser et al., 2006). Furthermore, in another experiment with soils from a field compaction trial, the production of $\mathrm{N}_{2} \mathrm{O}$ during the first $24 \mathrm{~h}$ following rewetting of dry soil was nearly 20 times higher in compacted than in uncompacted soil (Beare et al., 2009).

The magnitude of increased $\mathrm{N}_{2} \mathrm{O}$ flux following thawing of frozen soils is influenced by soil texture (Christensen and Christensen, 1991; Lemke, 1998), crop species (Kaiser et al., 1998; Johnson et al., 2010), forest type (Teepe and Ludwig, 2004), tillage history (Singurindy et al., 2009), soil water content (Koponen and Martikainen, 2004; Wolf et al., 2010), the length of the freezing period (Papen and Butterbach-Bahl, 1999; Wagner-Riddle et al., 2007; Dietzel et al., 2011), and the degree of ice formation (Wagner-Riddle et al., 2010). Soils with clay-dominated aggregates are prone to high $\mathrm{N}_{2} \mathrm{O}$ flux during thawing periods (van Bochove et al., 2000; Müller et al., 2003). However, there is little information on the subsequent effect of soil water content on $\mathrm{N}_{2} \mathrm{O}$ fluxes (Röver et al., 1998; van Bochove et al., 2000). For example, Röver et al. (1998) measured large fluxes of $\mathrm{N}_{2} \mathrm{O}$ after freezing in an agricultural soil at $80 \%$ water-filled pore space, while van Bochove et al. (2000) reported that the $\mathrm{N}_{2} \mathrm{O}$ fluxes from a clay soil were significantly larger at a volumetric water content of $39 \%$ than at $28 \%$.

\subsubsection{Nitric oxide}

The magnitude of increased NO flux can be influenced by the duration and severity of antecedent dry periods (ButterbachBahl et al., 2004; McCalley and Sparks, 2008), change in soil moisture (Yienger and Levy, 1995) and temperature (Smart et al., 1999; McCalley and Sparks, 2008), vegetation type (Barger et al., 2005; McCalley and Sparks, 2008), soil type (Martin et al., 2003), microbial demand for N (Stark et al., 2002), frequency of wetting events (Davidson et al., 1991; Hartley and Schlesinger, 2000), previous disturbances (Levine et al., 1988; Poth et al., 1995), and agricultural management (Hutchinson and Brams, 1992). Interestingly, there are conflicting results on the magnitude of increased NO flux after rewetting, which were independent of both the size of rewetting pulse (Davidson, 1992b; Martin et al., 1998) and the periods of antecedent dry days (Martin et al., 1998). Also, other reports have suggested that lower amounts of water addition result in higher NO pulses (Hutchinson et al., 1997; Dick et al., 2001). These conflicting results emphasize the uncertainty and limitations of predicting the magnitude of NO flux responses to soil rewetting.

\subsubsection{Ammonia}

The magnitude of increased $\mathrm{NH}_{3}$ flux following rewetting of dry soils may be influenced by land cover type and soil temperature (Schlesinger and Peterjohn, 1991; McCalley and Sparks, 2008).

However, it is important to recognize the lack of studies on soil $\mathrm{NH}_{3}$ flux represented in our database $(\sim 2 \%)$.

\section{Effects of rewetting and thawing on soil gas fluxes: analysis of a database}

Here we present results from an analysis of the database "A Global Database of Gas Fluxes from Soils after Rewetting or Thawing, Version 1.0)". We found that increases in $\mathrm{CO}_{2}, \mathrm{~N}_{2} \mathrm{O}$ and $\mathrm{NO}$ fluxes following rewetting were negatively correlated to pre-change flux (total $n=112$; Fig. 5, Table 4); that is, soils producing lower gas fluxes in dry conditions showed greater flux increases following rewetting. This likely occurs because drier soil conditions cause lower soil gas fluxes, but also greater accumulation of substrates, promoting large fluxes following rewetting (Orchard and Cook, 1983; Yanai et al., 2007; Unger et al., 2010). This finding is consistent with results from many previous studies (Orchard and Cook, 1983; Ruser et al., 2006; Yanai et al., 2007; Cable et al., 2008).

We also found a positive relationship between $\mathrm{N}_{2} \mathrm{O}$ flux increases following thawing and mean annual temperature (MAT) $(n=21$; Fig. 6, Table 5), implying that soils in warmer climates exhibit greater $\mathrm{N}_{2} \mathrm{O}$ flux increases following thawing than colder climate soils. This result contrasts with previous individual studies showing that colder and longer-frozen soils have greater flux increases following thawing (Papen and Butterbach-Bahl, 1999; Wagner-Riddle et al., 2007, 2010; Dietzel et al., 2011). A partial explanation may be that warmer regions have higher labile substrate inputs (i.e., fine roots, microbial biomass, soil organic matters), which accumulate in soils during frozen periods and contribute to larger gas fluxes following thawing.

Finally, we found that $\mathrm{CO}_{2}$ flux responses were positively related with MAT, while $\mathrm{N}_{2} \mathrm{O}$ and $\mathrm{NO}$ flux responses were negatively related to MAT (all marginally significant) ( $n=82$; Fig. 6, Table 5). These relationships are not well explained by our current understanding about mechanisms and drivers of gas flux increase following rewetting, and further studies are needed to determine if these patterns can be generalized to other sites and regions. 
Table 4. Summary statistics of relationship between mean pre-change flux and flux change (i.e. peak flux as a percentage of pre-event flux) by gas and rewetting or thawing (Fig. 5).

\begin{tabular}{llllll}
\hline Event type & Gas type & Intercept & Slope & Slope F-statistic & Slope p-value \\
\hline Rewetting & $\mathrm{CO}_{2}$ & $4.527 \pm 0.296$ & $-0.902 \pm 0.125$ & 52.35 & $<0.0001$ \\
Rewetting & $\mathrm{N}_{2} \mathrm{O}$ & $2.478 \pm 0.250$ & $-0.421 \pm 0.130$ & 10.53 & 0.003 \\
Rewetting & $\mathrm{NO}$ & $2.578 \pm 0.175$ & $-0.242 \pm 0.102$ & 5.601 & 0.021 \\
\hline
\end{tabular}

Table 5. Summary statistics of relationship between mean annual temperature and flux change (i.e. peak flux as a percentage of pre-event flux) by gas and rewetting or thawing (Fig. 6).

\begin{tabular}{llllll}
\hline Event type & Gas type & Intercept & Slope & Slope F-statistic & Slope p-value \\
\hline Rewetting & $\mathrm{CO}_{2}$ & $2.133 \pm 0.214$ & $0.037 \pm 0.021$ & 3.315 & 0.089 \\
Rewetting & $\mathrm{N}_{2} \mathrm{O}$ & $3.800 \pm 0.347$ & $-0.033 \pm 0.017$ & 3.871 & 0.058 \\
Rewetting & $\mathrm{NO}$ & $4.055 \pm 0.333$ & $-0.036 \pm 0.017$ & 3.619 & 0.072 \\
Thawing & $\mathrm{N}_{2} \mathrm{O}$ & $2.540 \pm 0.280$ & $0.154 \pm 0.049$ & 10 & 0.005 \\
\hline
\end{tabular}

\section{Knowledge gaps and future directions}

\subsection{Challenges in understanding the responses and mechanisms of soil gas fluxes}

Overall, the scientific community lacks a good understanding of both the responses and mechanisms of soil gases following rewetting or thawing and their impact on annual budgets. Many studies report the magnitude of peak flux or increased rate of flux following rewetting or thawing, but often do not identify: (1) whether peak fluxes are significantly different from fluxes of pre-drought or pre-frozen periods, (2) the change in soil moisture or soil temperature, (3) the time lag between rewetting or thawing events and peak fluxes, (4) peak flux durations, (5) cumulative emissions in peak fluxes, and (6) their contributions to annual budgets. Efforts to collect such information will contribute to improving our understanding of the response of gas fluxes to rewetting and thawing events. Compared to $\mathrm{CO}_{2}$ and $\mathrm{N}_{2} \mathrm{O}$ fluxes, our understanding of the effect of rewetting and thawing on $\mathrm{CH}_{4}$, $\mathrm{NO}$ and $\mathrm{NH}_{3}$ fluxes and mechanisms and drivers of the variation is limited, as shown in our database. We encourage the scientific community to perform experiments and observations to better understand their magnitudes and mechanisms.

Changes in the relative proportion of $\mathrm{CO}_{2}, \mathrm{CH}_{4}, \mathrm{~N}_{2} \mathrm{O}$, $\mathrm{NO}$ and $\mathrm{NH}_{3}$ (e.g., $\mathrm{CO}_{2} / \mathrm{CH}_{4} ; \mathrm{CO}_{2} / \mathrm{N}_{2} \mathrm{O}$ ) emitted following rewetting and thawing compared with that of pre-disturbance conditions are poorly understood. To report these ratios and the change, additional efforts are required to conduct multiple gases measurements. This is important since the different mechanisms would be involved in changing the relative proportion of the emissions and a good understanding of the variation of the relative proportion could improve our understanding of the impact of rewetting or thawing on annual gas budgets.
How soils underlying different vegetation types respond to rewetting and thawing events (Teepe and Ludwig, 2004; Matzner and Borken, 2008; Kim et al., 2010b; Shi et al., 2011) is also a research frontier. This is important because different vegetation types can have different phenologies and photosynthesis rates (Vargas et al., 2010b), nutrient cycling rates in detritus (Vogt et al., 1986), and soils (Borken and Beese, 2005; Paré et al., 2006). Plant-mediated effects on soil microclimate, such as soil temperature and soil moisture (Raich and Schlesinger, 1992; Aussenac, 2000), and plant mediated effects on root, rhizomorph (Vargas and Allen, 2008) and mycorrhizae (Heinemeyer et al., 2012) dynamics are also only beginning to be explored. Novel mechanisms and pathways by which plants emit gas have been explored recently (Smart and Bloom, 2001; Pihlatie et al., 2005; Keppler et al., 2006; Aubrey and Teskey, 2009; Gauci et al., 2010), but how these pathways respond to rewetting or thawing events are not well understood. Furthermore, the relative importance of source processes responsible for the increased fluxes of $\mathrm{CO}_{2}$ (i.e., autotrophic or heterotrophic activity), $\mathrm{NO}$ and $\mathrm{N}_{2} \mathrm{O}$ (i.e., nitrification, denitrification or nitrifier denitrification) is poorly understood. Finally, the effect of rewetting and thawing on dissolved soil gas has been only rarely studied (Matzner and Borken, 2008). To our knowledge, there is only one study showing indirect evidence of this effect, which found that in spring rainfall after thawing increased concentration of dissolved $\mathrm{N}_{2} \mathrm{O}$ in soil solutions in forest (Xu et al., 2009). These results suggest that the increased $\mathrm{N}_{2} \mathrm{O}$ following rewetting can be dissolved in the soil solution (Xu et al., 2009). This $\mathrm{N}_{2} \mathrm{O}$ in the soil solution can drain to surface or groundwater, and be a source of indirect $\mathrm{N}_{2} \mathrm{O}$ flux (IPCC, 2006). It is therefore important to understand and quantify the effect of rewetting and thawing on dissolved soil gases. 


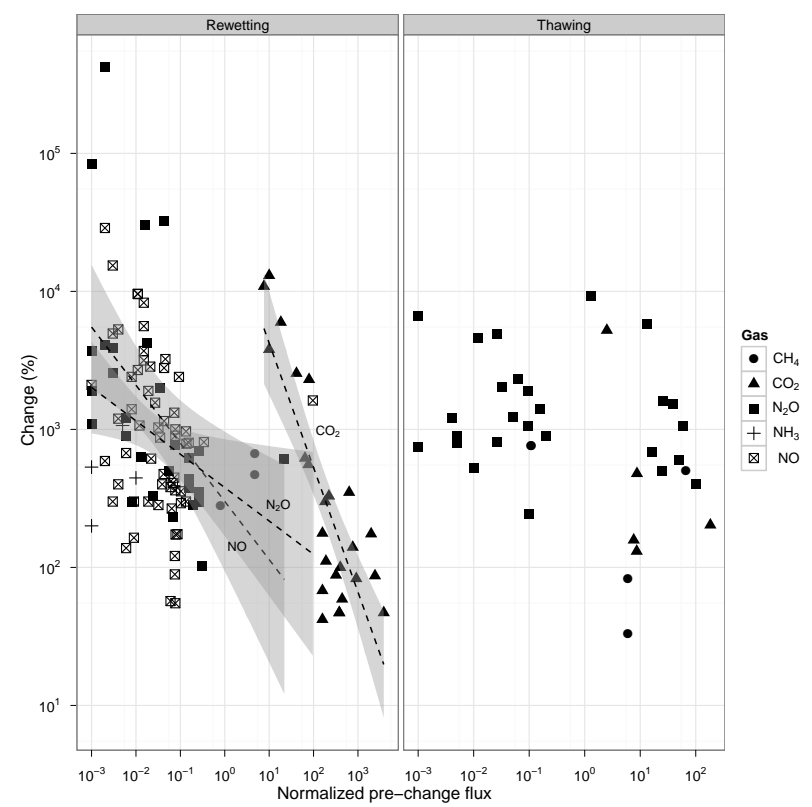

Fig. 5. Pre-change flux (normalized to common units of mg gas $\mathrm{m}^{-2} \mathrm{~h}^{-1}$ for field measurements, and mg gas kg ${ }^{-1} \mathrm{~h}^{-1}$ for lab incubations) versus flux change (i.e. peak flux as a percentage of pre-event flux), by gas and rewetting or thawing. Only statistically significant relationships (for $\mathrm{CO}_{2}, \mathrm{~N}_{2} \mathrm{O}$ and $\mathrm{NO}$ on left) are shown.

\subsection{Temporal and spatial resolution}

Considering the short response time and short effective period of the pulse in soil gas fluxes, many peak fluxes might have been missed in previous studies (see Fig. 2), as frequently only a few manual measurements were used (Joos et al., 2010; Maljanen et al., 2010). The lack of temporal sampling resolution may also influence the estimation of annual fluxes. In contrast, substantial rewetting effects have been frequently observed with automated chamber systems (Borken et al., 1999: 4-5 observations per day), eddy covariance methods (cf. Lee et al., 2004; Kim et al., 2010a), and automated measurements of soil $\mathrm{CO}_{2}$ profiles (Vargas et al., 2010b). Such continuous flux measurements during and after pulse events will help calculate the temporaldynamics and the total contribution to the cumulative flux and annual flux (Maljanen et al., 2010; Vargas et al., 2010a). When manual chamber methods have to be used, more frequent measurements (Smith and Dobbie, 2001; Parkin, 2008) or measurements coinciding with rewetting or thawing events (Beare et al., 2009; Kim et al., 2010b) should be considered.

Most studies have explored the effects of rewetting and thawing at small spatial scales (i.e., plot level). Thus, a critical issue is how to scale up to the ecosystem, landscape or continental scale. Rewetting and thawing pulses may be patchily distributed in space, and without measurements in various spatial and temporal scales (i.e., chambers, eddy covariance, upscaling through remote sensing) it is difficult

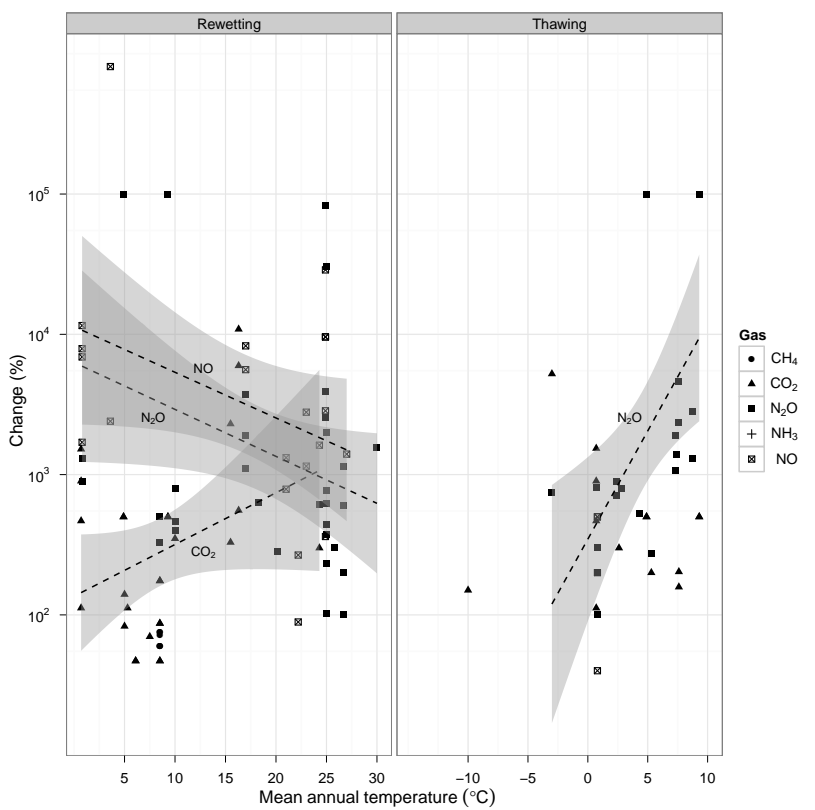

Fig. 6. Mean annual temperature versus flux change (i.e. peak flux as a percentage of pre-event flux), by gas and rewetting or thawing. Only statistically significant relationships (for $\mathrm{CO}_{2}, \mathrm{~N}_{2} \mathrm{O}$ and $\mathrm{NO}$ on left, and $\mathrm{N}_{2} \mathrm{O}$ on right) are shown.

to evaluate the impacts of these events across regions of the Earth. Although multi-spatial scale sampling is needed, we recognize that there is frequently a cost trade-off between temporal sampling and spatial sampling. However, with improving technologies and the growth of continental and global networks (i.e., NEON, ICOS, FLUXNET), multitemporal and multi-scale experiments will become more common in the near future.

\subsection{Experimental designs}

To test the effect of rewetting and thawing on soil gas flux, controlled experiments have been frequently conducted both in field and laboratory settings using, for example, rainfall exclusions (Borken et al., 2006; Davidson et al., 2008), snow removal (Groffman et al., 2006; Maljanen et al., 2007), and soil cores incubated in the lab (Panikov and Dedysh, 2000). However, these conditions may not accurately simulate natural conditions (Henry, 2007). Future experiments might: (1) simulate drying-rewetting and freezing-thawing based on historical or projected extreme events, the latter under multiple climate change scenarios (Jentsch et al., 2007); (2) collect soil samples in the appropriate season and include relevant surface factors such as plant litter in the autumn or excess water in the spring (Henry, 2007); and (3) develop new methods for simulating field conditions more closely in the laboratory (Hu et al., 2006). Future studies could benefit from these approaches in combination with high-temporal frequency resolution using automated flux measurements. 
An area of significant promise involves combining microbial community analyses (Kim et al., 2008; Smith et al., 2010; Sawicka et al., 2009) and/or stable isotope techniques (Wagner-Riddle et al., 2008; Goldberg and Gebauer, 2009; Gaudinski et al., 2009; Unger et al., 2012) with flux measurements. Whether performed in the lab or field, such experiments could improve our understanding of rewetting and thawing effect on soil gas fluxes, identifying source processes and mechanisms and quantifying their contributions to overall responses.

\subsection{Model improvement}

Models are promising tools for evaluating the importance of drying-rewetting and freeze-thaw events (Groffman et al., 2009). Simple linear regressions and empirical models have been developed based on the relationships between environmental factors, including soil moisture and/or soil temperature and soil gas fluxes (Roelandt et al., 2005; Flechard et al., 2007). Some rely on empirical observations but fail under rewetting or thawing conditions (Borken et al., 2003; Lawrence et al., 2009). We propose that further work in this area will increasingly have to incorporate non-linearities in the flux response and the actual substrate and microbial dynamics occurring (Davidson and Janssens, 2006; Vargas et al., 2011).

Process-based models have been developed with the objective of simulating terrestrial ecosystem $\mathrm{C}$ and $\mathrm{N}$ biogeochemistry including GHGs (e.g. DAYCENT, Parton et al., 2001; DNDC, Li et al., 1992; ecosys, Grant and Pattey, 2003). Most existing process-based models require additional work to improve simulating rewetting and thawing effect on soil gas fluxes (Jarecki et al., 2009; Norman et al., 2008; Kariyapperuma et al., 2011; Wolf et al., 2012). Groffman et al. (2009) suggested that modelling peak fluxes associated with drying and rewetting events requires: (1) accurate simulation of moisture changes in different soil layers and complex shifts in utilisation of fast- and slow-cycling soil organic matter pools by microbes that take place during these events (Miller et al., 2005), and (2) daily or sub-daily simulations of both physical and biological processes (Kiese et al., 2005). They also suggested that the modelling of freeze-thaw induced $\mathrm{N}_{2} \mathrm{O}$ fluxes requires consideration of the increase in easily degradable substrates following freezing, tight coupling of nitrification and denitrification in the water saturated topsoil, and the breakdown of $\mathrm{N}_{2} \mathrm{O}$ reductase activity at low temperature (Holtan-Hartwig et al., 2002). Another processbased modelling study found that including decreases in hydraulic conductivity in frozen soil improved the simulation of pulse $\mathrm{N}_{2} \mathrm{O}$ emissions following thawing (Wolf et al., 2012). Regardless of the specific process under consideration, it is critical to enhance the communication between field scientists and the modelling community, as models can be used to generate hypotheses (de Bruijn et al., 2009) to be tested in the field and laboratory.

\section{Conclusions}

Rewetting and thawing events are important short-term transitional and non-stationary phenomena in terms of hydrology and the thermodynamics of soil systems. Through this review and the compiled database, we identified that major soil gases such as $\mathrm{CO}_{2}, \mathrm{CH}_{4}, \mathrm{~N}_{2} \mathrm{O}, \mathrm{NO}$ and $\mathrm{NH}_{3}$ are influenced substantially by these events. The responses of these gases to rewetting and thawing events are critical for our understanding of $\mathrm{C}$ and $\mathrm{N}$ dynamics and land-atmosphere gas exchange. The mechanisms that control these fluxes during rewetting and thawing events are not fully understood, but enhanced microbial metabolism by substrate supply and changed soil physical properties influencing gas flux are accepted as the main mechanisms responsible for changes in all the gases we considered. An analysis of the compiled dataset showed that lower initial (pre-change) fluxes of $\mathrm{CO}_{2}, \mathrm{~N}_{2} \mathrm{O}$ and $\mathrm{NO}$ tend to be associated with greater flux increases following rewetting. Additionally, increases in $\mathrm{N}_{2} \mathrm{O}$ flux following thawing were greater in warmer climate soils than in colder soils. Future climatic change is likely to alter the frequency and intensity of drying-rewetting events and thawing of frozen soils. Thus, rewetting and thawing events could become more critical for land-atmosphere gas exchange and may be more important to incorporate in biogeochemical models. Advancements in this research field are likely to come from high frequency measurements of gas fluxes, soil microbial analyses, isotope measurements, and stronger collaborations between the process-based modelling community and the experimental scientific community.

\section{Appendix A}

\section{A Blog for open discussion and web based open databases}

We have created a blog (web-based discussion) entitled "Rewetting, thawing and soil gas fluxes" (http:// rewettingandthawing.blogspot.com/) and we have uploaded a current version of this review paper section by section as an individual post in the Blog; comments can be left under the separate posts. An open-access database, which can be modified by the users, is linked to the Blog: "Rewetting, thawing and soil gas fluxes database" (https://spreadsheets.google.com/spreadsheet/ccc?key $=0 \mathrm{Aj}$ Wu6bR8SA9idHY4Tk5TdDZDMWgtMEJsUVhFOWhKL Wc\&hl=en_US). The database contains detailed information in the reported studies on soil gas peak flux following rewetting and thawing. The database is hosted in webbased spreadsheets and is easily accessible and modified. The authors do not have any relationship with the companies currently being used to host the Blog and databases. Finally, version 1 of this database has been archived at the Oak Ridge National Laboratory Distributed Active Archive Center (http://daac.ornl.gov/SOILS/guides/global_rtsg_flux 
v1.html; A Global Database of Gas Fluxes from Soils after Rewetting or Thawing, Version 1.0) and is available for reproducing the results presented in this study.

Acknowledgements. We are grateful for the numerous researchers and technicians who provided invaluable data. It is impossible to cite all the references due to limited space allowed and we apologize for the authors whose work has not been cited. We are also grateful to Yit Arn Teh, Gerhard Gebauer, James Raich, Kevin Tate, Klaus Butterbach-Bahl, Miko Kirschbaum, Tom Misselbrook, Tomoaki Morishita, Sara Marañón-Jiménez, Stephan Unger, Ana Rey and an anonymous reviewer for constructive and valuable comments. We thank Leslie Hook at the Oak Ridge National Laboratory Distributed Active Archive Center, and Anne Austin for editing. R.V. was partially funded by CONACyT grants (145074, 152671) while writing this manuscript.

Edited by: M. Bahn

\section{References}

Anisimov, O. A.: Potential feedback of thawing permafrost to the global climate system through methane emission, Environ. Res. Lett., 2, 045016, doi:10.1088/1748-9326/2/4/045016, 2007.

Appel, T.: Non-biomass soil organic $\mathrm{N}$ - the substrate for $\mathrm{N}$ mineralization flushes following soil drying-rewetting and for organic $\mathrm{N}$ rendered $\mathrm{CaCl}_{2}$-extractable upon soil drying, Soil Biol. Biochem., 30, 1445-1456, 1998.

Aubrey, D. P. and Teskey, R. O.: Root-derived $\mathrm{CO}_{2}$ efflux via xylem stream rivals soil $\mathrm{CO}_{2}$ efflux, New Phytol., 184, 35-40, doi:10.1111/j.1469-8137.2009.02971.x, 2009.

Aussenac, G.: Interactions between forest stands and microclimate: ecophysiological aspects and consequences for silviculture, Ann. For. Sci, 57, 287-301, 2000.

Austin, A. T., Yahdjian, L., Stark, J. M., Belnap, J., Porporato, A., Norton, U., Ravetta, D. A., and Schaeffer, S. M.: Water pulses and biogeochemical cycles in arid and semiarid ecosystems, Oecologia, 141, 221-235, 2004.

Ball, B. C., Scott, A., and Parker, J. P.: Field $\mathrm{N}_{2} \mathrm{O}, \mathrm{CO}_{2}$ and $\mathrm{CH}_{4}$ fluxes in relation to tillage, compaction and soil quality in Scotland, Soil Till. Res., 53, 29-39, 1999.

Balser, T. C. and Firestone, M. K.: Linking microbial community composition and soil processes in a California annual grassland and mixed-conifer forest, Biogeochemistry, 73, 395-415, doi:10.1007/s10533-004-0372-y, 2005.

Barger, N., Belnap, J., Ojima, D., and Mosier, A.: NO gas loss from biologically crusted soils in Canyonlands national park, Utah, Biogeochemistry, 75, 373-391, 2005.

Barton, L., Kiese, R., Gatter, D., Butterbach-Bahl, K., Buck, R., Hinz, C., and Murphy, D. V.: Nitrous oxide emissions from a cropped soil in a semi-arid climate, Global Change Biol., 14, 177-192, 2008

Beare, M. H., Gregorich, E. G., and St-Georges, P.: Compaction effects on $\mathrm{CO}_{2}$ and $\mathrm{N}_{2} \mathrm{O}$ production during drying and rewetting of soil, Soil Biol. Biochem., 41, 611-621, doi:10.1016/j.soilbio.2008.12.024, 2009.

Birch, H.: The effect of soil drying on humus decomposition and nitrogen availability, Plant Soil, 10, 9-31, 1958.
Blankinship, J. C. and Hart, S. C.: Consequences of manipulated snow cover on soil gaseous emission and $\mathrm{N}$ retention in the growing season: a meta-analysis, Ecosphere, 3, art1, doi:10.1890/es11-00225.1, 2012.

Blodau, C. and Moore, T. R.: Micro-scale $\mathrm{CO}_{2}$ and $\mathrm{CH}_{4}$ dynamics in a peat soil during a water fluctuation and sulfate pulse, Soil Biol. Biochem., 35, 535-547, 2003.

Bobbink, R., Heil, G. W., and Raessen, M. B. A. G.: Atmospheric deposition and canopy exchange processes in heathland ecosystems, Environ. Poll., 75, 29-37, 1992.

Borken, W. and Beese, F.: Soil respiration in pure and mixed stands of European beech and Norway spruce following removal of organic horizons, Can. J. Forest Res., 35, 2756-2764, 2005.

Borken, W. and Matzner, E.: Reappraisal of drying and wetting effects on $\mathrm{C}$ and $\mathrm{N}$ mineralization and fluxes in soils, Global Change Biol., 15, 808-824, 2009.

Borken, W., Xu, Y. J., Brumme, R., and Lamersdorf, N.: A climate change scenario for carbon dioxide and dissolved organic carbon fluxes from a temperate forest soil: Drought and rewetting effects, Soil Sci. Soc. Am. J., 63, 1848-1855, 1999.

Borken, W., Davidson, E. A., Savage, K., Gaudinski, J., and Trumbore, S. E.: Drying and wetting effects on carbon dioxide release from organic horizons, Soil Sci. Soc. Am. J., 67, 1888-1896, 2003.

Borken, W., Davidson, E. A., Savage, K., Sundquist, E. T., and Steudler, P.: Effect of summer throughfall exclusion, summer drought, and winter snow cover on methane fluxes in a temperate forest soil, Soil Biol. Biochem., 38, 1388-1395, 2006.

Brooks, P., Schmidt, S., and Williams, M.: Winter production of $\mathrm{CO}_{2}$ and $\mathrm{N}_{2} \mathrm{O}$ from alpine tundra: Environmental controls and relationship to inter-system $\mathrm{C}$ and $\mathrm{N}$ fluxes, Oecologia, 110, 403413, 1997.

Butterbach-Bahl, K., Kock, M., Willibald, G., Hewett, B., Buhagiar, S., Papen, H., and Kiese, R.: Temporal variations of fluxes of $\mathrm{NO}, \mathrm{NO}_{2}, \mathrm{~N}_{2} \mathrm{O}, \mathrm{CO}_{2}$, and $\mathrm{CH}_{4}$ in a tropical rain forest ecosystem, Global Biogeochem. Cy., 18, GB3012, doi:10.1029/2004GB002243, 2004

Cable, J. M., Ogle, K., Williams, D. G., Weltzin, J. F., and Huxman, T. E.: Soil texture drives responses of soil respiration to precipitation pulses in the Sonoran Desert: Implications for climate change, Ecosystems, 11, 961-979, doi:10.1007/s10021008-9172-x, 2008.

Casals, P., Lopez-Sangil, L., Carrara, A., Gimeno, C., and Nogués, S.: Autotrophic and heterotrophic contributions to short-term soil $\mathrm{CO}_{2}$ efflux following simulated summer precipitation pulses in a Mediterranean dehesa, Global Biogeochem. Cy., 25, GB3012, doi:10.1029/2010gb003973, 2011.

Castaldi, S., de Grandcourt, A., Rasile, A., Skiba, U., and Valentini, R.: $\mathrm{CO}_{2}, \mathrm{CH}_{4}$ and $\mathrm{N}_{2} \mathrm{O}$ fluxes from soil of a burned grassland in Central Africa, Biogeosciences, 7, 3459-3471, doi:10.5194/bg7-3459-2010, 2010.

Chanton, J. P.: The effect of gas transport on the isotope signature of methane in wetlands, Org. Geochem., 36, 753-768, 2005.

Chen, S., Lin, G., Huang, J., and Jenerette, G. D.: Dependence of carbon sequestration on the differential responses of ecosystem photosynthesis and respiration to rain pulses in a semiarid steppe, Global Change Biol., 15, 2450-2461, 2009.

Chen, Y., Tessier, S., Mackenzie, A. F., and Laverdiere, M. R.: Nitrous oxide emission from an agricultural soil subjected to dif- 
ferent freeze-thaw cycles, Agr. Ecosyst. Environ., 55, 123-128, 1995.

Chou, W. W., Silver, W. L., Jackson, R. D., Thompson, A. W., and Allen-Diaz, B.: The sensitivity of annual grassland carbon cycling to the quantity and timing of rainfall, Global Change Biol., 14, 1382-1394, doi:10.1111/j.1365-2486.2008.01572.x, 2008.

Christensen, S. and Christensen, B. T.: Organic-matter available for denitrification in different soil fractions-effect of freeze thaw cycles and straw disposal, J. Soil Sci., 42, 637-647, 1991.

Christensen, S. and Tiedje, J. M.: Brief and vigorous $\mathrm{N}_{2} \mathrm{O}$ production by soil at spring thaw, J. Soil Sci., 41, 1-4, 1990.

Christensen, T. R., Johansson, T., Åkerman, H. J., Mastepanov, M., Malmer, N., Friborg, T., Crill, P., and Svensson, B. H.: Thawing sub-arctic permafrost: Effects on vegetation and methane emissions, Geophys. Res. Lett., 31, L04501, doi:10.1029/2003g1018680, 2004.

Clein, J. S. and Schimel, J. P.: Reduction in microbial activity in birch litter due to drying and rewetting events, Soil Biol. Biochem., 26, 403-406, 1994.

Coulthard, T. J., Baird, A. J., Ramirez, J., and Waddington, J. M.: Methane dynamics in peat: Importance of shallow peats and a novel reduced-complexity approach for modeling ebullition, in Carbon Cycling in Northern Peatlands, edited by: Baird, A. J., Belyea, L. R., Comas, X., Reeve, A. S., and Slater, L. D., Geoph. Monog. Series, 184, 173-185, doi:10.1029/2008GM000811, 2009.

Coxson, D. and Parkinson, D.: Winter respiratory activity in aspen woodland forest floor litter and soils, Soil Biol. Biochem., 19, 49-59, 1987.

Crow, S. E. and Wieder, R. K.: Sources of $\mathrm{CO}_{2}$ emission from a northern peatland: root respiration, exudation, and decomposition, Ecology, 86, 1825-1834, 2005.

Curiel Yuste, J., Baldocchi, D. D., Gershenson, A., Goldstein, A., Misson, L., and Wong, S.: Microbial soil respiration and its dependency on carbon inputs, soil temperature and moisture, Global Change Biol., 13, 2018-2035, doi:10.1111/j.13652486.2007.01415.x, 2007.

Czepiel, P., Crill, P., and Harriss, R.: Environmental factors influencing the variability of methane oxidation in temperate zone soils, J. Geophys. Res., 100, 9359-9364, 1995.

Davidson, E. A.: Pulses of nitric oxide and nitrous oxide flux following wetting of dry soil: An assessment of probable sources and importance relative to annual fluxes, Ecol. Bull., 42, 149155, 1992a.

Davidson, E. A.: Sources of nitric oxide and nitrous oxide following wetting of dry soil, Soil Sci. Soc. Am. J., 56, 95-102, 1992b.

Davidson, E. A. and Janssens, I. A.: Temperature sensitivity of soil carbon decomposition and feedbacks to climate change, Nature, 440, 165-173, 2006.

Davidson, E. A., Vitousek, P. M., Matson, P. A., Riley, R., GarcíaMéndez, G., and Maass, J. M.: Soil emissions of nitric oxide in a seasonally dry tropical forest of México, J. Geophys. Res., 96, 15439-15445, doi:10.1029/91jd01476, 1991.

Davidson, E., Matson, P., Vitousek, P., Riley, R., Dunkin, K., Garcia-Mendez, G., and Maass, J.: Processes regulating soil emissions of $\mathrm{NO}$ and $\mathrm{N}_{2} \mathrm{O}$ in a seasonally dry tropical forest, Ecology, 74, 130-139, 1993.

Davidson, E. A., Belk, E., and Boone, R. D.: Soil water content and temperature as independent or confounded factors controlling soil respiration in a temperate mixed hardwood forest, Global Change Biol., 4, 217-227, 1998.

Davidson, E. A., Verchot, L. V., Cattânio, J. H., Ackerman, I. L., and Carvalho, J.: Effects of soil water content on soil respiration in forests and cattle pastures of eastern Amazonia, Biogeochemistry, 48, 53-69, 2000.

Davidson, E. A., Ishida, F. Y., and Nepstad, D. C.: Effects of an experimental drought on soil emissions of carbon dioxide, methane, nitrous oxide, and nitric oxide in a moist tropical forest, Global Change Biol., 10, 718-730, doi:10.1111/j.13652486.2004.00762.x, 2004.

Davidson, E. A., Nepstad, D. C., Ishida, F. Y., and Brando, P. M.: Effects of an experimental drought and recovery on soil emissions of carbon dioxide, methane, nitrous oxide, and nitric oxide in a moist tropical forest, Global Change Biol., 14, 2582-2590, doi:10.1111/j.1365-2486.2008.01694.x, 2008.

de Bruijn, A. M. G., Butterbach-Bahl, K., Blagodatsky, S., and Grote, R.: Model evaluation of different mechanisms driving freeze-thaw $\mathrm{N}_{2} \mathrm{O}$ emissions, Agr. Ecosyst. Environ., 133, 196207, 2009.

Dick, J., Skiba, U., and Wilson, J.: The effect of rainfall on NO and $\mathrm{N}_{2} \mathrm{O}$ emissions from Ugandan agroforest soils, Phyton, 41, 73-80, 2001.

Dick, J., Skiba, U., Munro, R., and Deans, D.: Effect of N-fixing and non $\mathrm{N}$-fixing trees and crops on $\mathrm{NO}$ and $\mathrm{N}_{2} \mathrm{O}$ emissions from Senegalese soils, J. Biogeogr., 33, 416-423, doi:10.1111/j.13652699.2005.01421.x, 2006.

Dietzel, R., Wolfe, D., and Thies, J. E.: The influence of winter soil cover on spring nitrous oxide emissions from an agricultural soil, Soil Biol. Biochem., 43, 1989-1991, 2011.

Dilustro, J. J., Collins, B., Duncan, L., and Crawford, C.: Moisture and soil texture effects on soil $\mathrm{CO}_{2}$ efflux components in southeastern mixed pine forests, Forest Ecol. Manag., 204, 8797, 2005.

Ding, W. X. and Cai, Z. C.: Methane emission from natural wetlands in China: Summary of years 1995-2004 studies, Pedosphere, 17, 475-486, 2007.

Dinsmore, K., Skiba, U., Billett, M., and Rees, R.: Effect of water table on greenhouse gas emissions from peatland mesocosms, Plant Soil, 318, 229-242, 2009.

Dörsch, P., Palojärvi, A., and Mommertz, S.: Overwinter greenhouse gas fluxes in two contrasting agricultural habitats, Nutr. Cycl. Agroecosys., 70, 117-133, 2004.

Dutaur, L. and Verchot, L. V.: A global inventory of the soil $\mathrm{CH}_{4}$ sink, Global Biogeochem. Cy., 21, GB4013, doi:10.1029/2006gb002734, 2007.

Elberling, B. and Brandt, K. K.: Uncoupling of microbial $\mathrm{CO}_{2}$ production and release in frozen soil and its implications for field studies of arctic C cycling, Soil Biol. Biochem., 35, 263-272, 2003.

Elberling, B., Christiansen, H. H., and Hansen, B. U.: High nitrous oxide production from thawing permafrost, Nat. Geosci., 3, 332335, doi:10.1038/ngeo803, 2010.

Estop-Aragonés, C. and Blodau, C.: Effects of experimental drying intensity and duration on respiration and methane production recovery in fen peat incubations, Soil Biol. Biochem., 47, 1-9, 2012.

Fernández, D. P., Neff, J. C., Belnap, J., and Reynolds, R. L.: Soil respiration in the cold desert environment of the Colorado 
Plateau (USA): Abiotic regulators and thresholds, Biogeochemistry, 78, 247-265, doi:10.1007/s10533-005-4278-0, 2006.

Fetzer, S., Bak, F., and Conrad, R.: Sensitivity of methanogenic bacteria from paddy soil to oxygen and desiccation, FEMS Microbiol. Ecol., 12, 107-115, 1993.

Fiedler, S., Lamers, M., Ingwersen, J., Streck, T., Stahr, K., and Jungkunst, H. F.: Impact of the heatwave in 2003 on the summer $\mathrm{CH}_{4}$ budget of a spruce forest with large variation in soil drainage: A four-year comparison (2001-2004), J. Plant Nutr. Soil Sc., 171, 666-671, doi:10.1002/jpln.200700248, 2008.

Fierer, N. and Schimel, J. P.: A proposed mechanism for the pulse in carbon dioxide production commonly observed following the rapid rewetting of a dry soil, Soil Sci. Soc. Am. J., 67, 798-805, 2003.

Flechard, C., Ambus, P., Skiba, U., Rees, R., Hensen, A., Van Amstel, A., Dasselaar, A., Soussana, J. F., Jones, M., and CliftonBrown, J.: Effects of climate and management intensity on nitrous oxide emissions in grassland systems across Europe, Agr. Ecosyst. Environ., 121, 135-152, 2007.

Francis, D. D., Vigil, M. F., and Moiser, A. R.: Gaseous losses of nitrogen other than through denitrification, in: Nitrogen in agricultural systems, edited by: Schepers, J. S. and Raun, W. R., Agronomy Monograph 49, American Society of Agronomy, Madison, WI, USA, 255-279, 2008.

Friborg, T., Christensen, T. R., and Sogaard, H.: Rapid response of greenhouse gas emission to early spring thaw in a subarctic mire as shown by micrometeorological techniques, Geophys. Res. Lett., 24, 3061-3064, 1997.

Furon, A., Wagner-Riddle, C., Smith, C., and Warland, J.: Wavelet analysis of wintertime and spring thaw $\mathrm{CO}_{2}$ and $\mathrm{N}_{2} \mathrm{O}$ fluxes from agricultural fields, Agr. Forest Meterol., 148, 1305-1317, 2008.

Garcia-Montiel, D. C., Steudler, P. A., Piccolo, M., Neill, C., Melillo, J., and Cerri, C. C.: Nitrogen oxide emissions following wetting of dry soils in forest and pastures in Rondonia, Brazil, Biogeochemistry, 64, 319-336, 2003.

Gauci, V., Cowing, D. J. G., Hornibrook, E. R. C., Davis, J. M., and Dise, N. B.: Woody stem methane emission in mature wetland alder trees, Atmos. Environ., 44, 2157-2160, doi:10.1016/j.atmosenv.2010.02.034, 2010.

Gaudinski, J. B., Torn, M. S., Riley, W. J., Swanston, C., Trumbore, S. E., Joslin, J. D., Majdi, H., Dawson, T. E., and Hanson, P. J.: Use of stored carbon reserves in growth of temperate tree roots and leaf buds: analyses using radiocarbon measurements and modeling, Global Change Biol., 15, 992-1014, doi:10.1111/j.1365-2486.2008.01736.x, 2009.

Ghude, S. D., Lal, D. M., Beig, G., van der A, R., and Sable, D.: Rain-induced soil $\mathrm{NO}_{\mathrm{x}}$ emission from India during the onset of the summer monsoon: A satellite perspective, J. Geophys. Res., 115, D16304, doi:10.1029/2009jd013367, 2010.

Goldberg, S. D. and Gebauer, G.: Drought turns a Central European Norway spruce forest soil from an $\mathrm{N}_{2} \mathrm{O}$ source to a transient $\mathrm{N}_{2} \mathrm{O}$ sink, Global Change Biol., 15, 850-860, doi:10.1111/j.13652486.2008.01752.x, 2009.

Goldberg, S. D., Muhr, J., Borken, W., and Gebauer, G.: Fluxes of climate-relevant trace gases between a Norway spruce forest soil and atmosphere during repeated freeze-thaw cycles in mesocosms, J. Plant Nutr. Soil Sc., 171, 729-739, 2008.

Goldberg, S. D., Knorr, K. H., Blodau, C., Lischeid, G., and Gebauer, G.: Impact of altering the water table height of an acidic fen on $\mathrm{N}_{2} \mathrm{O}$ and $\mathrm{NO}$ fluxes and soil concentrations, Global Change Biol., 16, 220-233, 2010a.

Goldberg, S. D., Borken, W., and Gebauer, G.: $\mathrm{N}_{2} \mathrm{O}$ emission in a Norway spruce forest due to soil frost: concentration and isotope profiles shed a new light on an old story, Biogeochemistry, 97 21-30, 2010b.

Goldhammer, T. and Blodau, C.: Desiccation and product accumulation constrain heterotrophic anaerobic respiration in peats of an ombrotrophic temperate bog, Soil Biol. Biochem., 40, $2007-$ 2015, doi:10.1016/j.soilbio.2008.03.005, 2008.

Grant, R. F. and Pattey, E.: Modelling variability in $\mathrm{N}_{2} \mathrm{O}$ emissions from fertilized agricultural fields, Soil Biol. Biochem., 35, 225243, 2003.

Green, S. and Baird, A.: A mesocosm study of the role of the sedge Eriophorum angustifolium in the efflux of methane - including that due to episodic ebullition - from peatlands, Plant Soil, 351, 207-218, doi:10.1007/s11104-011-0945-1, 2012.

Groffman, P. M. and Tiedje, J. M.: Denitrification hysteresis during wetting and drying cycles in soil, Soil Sci. Soc. Am. J., 52, 1626$1629,1988$.

Groffman, P. M., Hardy, J. P., Driscoll, C. T., and Fahey, T. J.: Snow depth, soil freezing, and fluxes of carbon dioxide, nitrous oxide and methane in a northern hardwood forest, Global Change Biol., 12, 1748-1760, doi:10.1111/j.1365-2486.2006.01194.x, 2006.

Groffman, P. M., Butterbach-Bahl, K., Fulweiler, R., Gold, A., Morse, J., Stander, E., Tague, C., Tonitto, C., and Vidon, P.: Challenges to incorporating spatially and temporally explicit phenomena (hotspots and hot moments) in denitrification models, Biogeochemistry, 93, 49-77, 2009.

Grogan, P., Michelsen, A., Ambus, P., and Jonasson, S.: Freezethaw regime effects on carbon and nitrogen dynamics in subarctic heath tundra mesocosms, Soil Biol. Biochem., 36, 641654, 2004.

Gu, L., Hanson, P. J., Mac Post, W., Kaiser, D. P., Yang, B., Nemani, R., Pallardy, S. G., and Meyers, T.: The 2007 eastern US spring freezes: Increased cold damage in a warming world?, Bioscience, 58, 253-262, doi:10.1641/b580311, 2008.

Guckland, A., Corre, M. D., and Flessa, H.: Variability of soil $\mathrm{N}$ cycling and $\mathrm{N}_{2} \mathrm{O}$ emission in a mixed deciduous forest with different abundance of beech, Plant Soil, 336, 25-38, doi:10.1007/s11104-010-0437-8, 2010.

Guenzi, W. D., Hutchinson, G. L., and Beard, W. E.: Nitric and nitrous oxide emissions and soil nitrate distribution in a centerpivot-irrigated cornfield, J. Environ. Qual., 23, 483-487, 1994.

Hanson, R. S. and Hanson, T. E.: Methanotrophic bacteria, Microbiol. Mol. Biol. Rev., 60, 439-471, 1996.

Hao, W. M., Scharffe, D., Crutzen, P. J., and Sanhueza, E.: Production of $\mathrm{N}_{2} \mathrm{O}, \mathrm{CH}_{4}$, and $\mathrm{CO}_{2}$ from soils in the tropical savanna during the dry season, J. Atmos. Chem., 7, 93-105, 1988.

Harms, T. K. and Grimm, N. B.: Responses of trace gases to hydrologic pulses in desert floodplains, J. Geophys. Res., 117, G01035, doi:10.1029/2011jg001775, 2012.

Harris, G. W., Wienhold, F. G., and Zenker, T.: Airborne observations of strong biogenic $\mathrm{NO}_{\mathrm{x}}$ emissions from the Namibian Savanna at the end of the dry season, J. Geophys. Res., 101, $23707-$ 23711, doi:10.1029/96jd01278, 1996.

Harris, R.: Effect of water potential on microbial growth and activity, in: Water potential relations in soil microbiology, edited by: Parr, J., Gardner, W., and Elliott, L., Soil Science Society of 
America, Madison, WI, USA, 23-97, 1981.

Hartley, A. E. and Schlesinger, W. H.: Environmental controls on nitric oxide emission from northern Chihuahuan desert soils, Biogeochemistry, 50, 279-300, 2000.

Heinemeyer, A., Wilkinson, M., Vargas, R., Subke, J.-A., Casella, E., Morison, J. I. L., and Ineson, P.: Exploring the "overflow tap" theory: linking forest soil $\mathrm{CO}_{2}$ fluxes and individual mycorrhizosphere components to photosynthesis, Biogeosciences, 9, 79-95, doi:10.5194/bg-9-79-2012, 2012.

Henry, H. A. L.: Soil freeze-thaw cycle experiments: trends, methodological weaknesses and suggested improvements, Soil Biol. Biochem., 39, 977-986, 2007.

Henry, H. A. L.: Climate change and soil freezing dynamics: historical trends and projected changes, Climatic Change, 87, 421-434, doi:10.1007/s10584-007-9322-8, 2008.

Hentschel, K., Borken, W., Zuber, T., Bogner, C., Huwe, B., and Matzner, E.: Effects of soil frost on nitrogen net mineralization, soil solution chemistry and seepage losses in a temperate forest soil, Global Change Biol., 15, 825-836, 2009.

Hergoualc'h, K., Skiba, U., Harmand, J.-M., and Hénault, C.: Fluxes of greenhouse gases from Andosols under coffee in monoculture or shaded by Inga densiflora in Costa Rica, Biogeochemistry, 89, 329-345, 2008.

Holst, J., Liu, C., Yao, Z., Brüggemann, N., Zheng, X., Giese, M., and Butterbach-Bahl, K.: Fluxes of nitrous oxide, methane and carbon dioxide during freezing-thawing cycles in an Inner Mongolian steppe, Plant Soil, 308, 105-117, 2008.

Holtan-Hartwig, L., Dörsch, P., and Bakken, L. R.: Low temperature control of soil denitrifying communities: kinetics of $\mathrm{N}_{2} \mathrm{O}$ production and reduction, Soil Biol. Biochem., 34, 1797-1806, 2002.

Hu, Q., Warland, E., Kay, J., and Wagner-Riddle, B.: New method to simulate soil freezing and thawing cycles for studying nitrous oxide flux, Soil Sci. Soc. Am. J., 70, 2106-2113, 2006.

Hu, Y., Chang, X., Lin, X., Wang, Y., Wang, S., Duan, J., Zhang, Z., Yang, X., Luo, C., Xu, G., and Zhao, X.: Effects of warming and grazing on $\mathrm{N}_{2} \mathrm{O}$ fluxes in an alpine meadow ecosystem on the Tibetan plateau, Soil Biol. Biochem., 42, 944-952, 2010.

Hutchinson, G. L. and Brams, E. A.: NO versus $\mathrm{N}_{2} \mathrm{O}$ emissions from an $\mathrm{NH}_{4}^{+}$amended Bermuda grass pastur, J. Geophys. Res., 97, 9889-9896, 1992.

Hutchinson, G. L., Guenzi, W. D., and Livingston, G. P.: Soil water controls on aerobic soil emission of gaseous nitrogen oxides, Soil Biol. Biochem., 25, 1-9, 1993.

Hutchinson, G. L., Vigil, M. F., Doran, J. W., and Kessavalou, A.: Coarse-scale soil-atmosphere $\mathrm{NO}_{\mathrm{x}}$ exchange modeling: status and limitations, Nutr. Cycl. Agroecosys., 48, 25-35, 1997.

Huxman, T. E., Snyder, K. A., Tissue, D., Leffler, A. J., Ogle, K., Pockman, W. T., Sandquist, D. R., Potts, D. L., and Schwinning, S.: Precipitation pulses and carbon fluxes in semiarid and arid ecosystems, Oecologia, 141, 254-268, doi:10.1007/s00442-0041682-4, 2004.

Intergovernmental Panel on Climate Change: IPCC Guidelines for National Greenhouse Gas Inventories, Prepared by the National Greenhouse Gas Inventories Programme, IGES, Japan, 2006.

Jager, G. and Bruins, E. H.: Effect of repeated drying at different temperatures on soil organic matter decomposition and characteristics, and on the soil microflora, Soil Biol. Biochem., 7, 153$159,1975$.
Jarecki, M., Parkin, T., Chan, A., Kaspar, T., Moorman, T., Singer, J., Kerr, B., Hatfield, J., and Jones, R.: Cover crop effects on nitrous oxide emission from a manure-treated Mollisol, Agr. Ecosyst. Environ., 134, 29-35, 2009.

Jarvis, P., Rey, A., Petsikos, C., Wingate, L., Rayment, M., Pereira, J., Banza, J., David, J., Miglietta, F., Borghetti, M., Manca, G., and Valentini, R.: Drying and wetting of Mediterranean soils stimulates decomposition and carbon dioxide emission: the "Birch effect", Tree Physiol., 27, 929-940, doi:10.1093/treephys/27.7.929, 2007.

Jensen, L. S., Mueller, T., Tate, K. R., Ross, D. J., Magid, J., and Nielsen, N. E.: Soil surface $\mathrm{CO}_{2}$ flux as an index of soil respiration in situ: A comparison of two chamber methods, Soil Biol. Biochem., 28, 1297-1306, doi:10.1016/S0038-0717(96)001368, 1996.

Jentsch, A., Kreyling, J., and Beierkuhnlein, C.: A new generation of climate-change experiments: events, not trends, Front. Ecol. Environ., 5, 365-374, 2007.

Joabsson, A., Christensen, T. R., and Wallén, B.: Vascular plant controls on methane emissions from northern peatforming wetlands, Trends Ecol. Evol., 14, 385-388, 1999.

Johnson, J. M. F., Archer, D., and Barbour, N.: Greenhouse gas emission from contrasting management scenarios in the northern corn belt, Soil Sci. Soc. Am. J., 74, 396-406, doi:10.2136/sssaj2009.0008, 2010.

Joos, O., Hagedorn, F., Heim, A., Gilgen, A. K., Schmidt, M. W. I., Siegwolf, R. T. W., and Buchmann, N.: Summer drought reduces total and litter-derived soil $\mathrm{CO}_{2}$ effluxes in temperate grassland - clues from a ${ }^{13} \mathrm{C}$ litter addition experiment, Biogeosciences, 7 , 1031-1041, doi:10.5194/bg-7-1031-2010, 2010.

Kaiser, E. A., Kohrs, K., Kucke, M., Schnug, E., Heinemeyer, O., and Munch, J. C.: Nitrous oxide release from arable soil: Importance of $\mathrm{N}$-fertilization, crops and temporal variation, Soil Biol. Biochem., 30, 1553-1563, 1998.

Kammann, C., Grunhage, L., Muller, C., Jacobi, S., and Jager, H. J.: Seasonal variability and mitigation options for $\mathrm{N}_{2} \mathrm{O}$ emissions from differently managed grasslands, Environ. Pollut., 102, 179186, 1998.

Kariyapperuma, K. A., Wagner-Riddle, C., Furon, A. C., and Li, C.: Assessing spring thaw nitrous oxide fluxes simulated by the DNDC model for agricultural soils, Soil Sci. Soc. Am. J., 75, 678-690, doi:10.2136/sssaj2010.0264, 2011.

Kemmitt, S. J., Lanyon, C. V., Waite, I. S., Wen, Q., Addiscott, T. M., Bird, N. R. A., O’Donnell, A. G., and Brookes, P. C.: Mineralization of native soil organic matter is not regulated by the size, activity or composition of the soil microbial biomass-a new perspective, Soil Biol. Biochem., 40, 61-73, doi:10.1016/j.soilbio.2007.06.021, 2008.

Keppler, F., Hamilton, J. T. G., Brass, M., and Rockmann, T.: Methane emissions from terrestrial plants under aerobic conditions, Nature, 439, 187-191, 2006.

Kessavalou, A., Doran, J. W., Mosier, A. R., and Drijber, R. A.: Greenhouse gas fluxes following tillage and wetting in a wheatfallow cropping system, J. Environ. Qual., 27, 1105-1116, 1998.

Kettunen, A., Kaitala, V., Alm, J., Silvola, J., Nykanen, H., and Martikainen, P. J.: Cross-correlation analysis of the dynamics of methane emissions from a boreal peatland, Global Biogeochem. Cy., 10, 457-471, 1996. 
Kettunen, A., Kaitala, V., Lehtinen, A., Lohila, A., Alm, J., Silvola, J., and Martikainen, P. J.: Methane production and oxidation potentials in relation to water table fluctuations in two boreal mires, Soil Biol. Biochem., 31, 1741-1749, 1999.

Kieft, T. L., Soroker, E., and Firestone, M. K.: Microbial biomass response to a rapid increase in water potential when dry soil is wetted, Soil Biol. Biochem., 19, 119-126, 1987.

Kiese, R., Li, C., Hilbert, D. W., Papen, H., and ButterbachBahl, K.: Regional application of PnET-N-DNDC for estimating the $\mathrm{N}_{2} \mathrm{O}$ source strength of tropical rainforests in the Wet Tropics of Australia, Global Change Biol., 11, 128-144, doi:10.1111/j.1365-2486.2004.00873.x, 2005.

Kim, D.-G., Mishurov, M., and Kiely, G.: Effect of increased N use and dry periods on $\mathrm{N}_{2} \mathrm{O}$ emission from a fertilized grassland, Nutr. Cycl. Agroecosys., 88, 397-410, doi:10.1007/s10705-0109365-5, 2010a.

Kim, D.-G., Mu, S., Kang, S., and Lee, D.: Factors controlling soil $\mathrm{CO}_{2}$ effluxes and the effects of rewetting on effluxes in adjacent deciduous, coniferous, and mixed forests in Korea, Soil Biol. Biochem., 42, 576-585, 2010b.

Kim, S.-Y., Lee, S.-H., Freeman, C., Fenner, N., and Kang, H.: Comparative analysis of soil microbial communities and their responses to the short-term drought in bog, fen, and riparian wetlands, Soil Biol. Biochem., 40, 2874-2880, 2008.

Kim, Y. and Tanaka, N.: Effect of forest fire on the fluxes of $\mathrm{CO}_{2}$, $\mathrm{CH}_{4}$ and $\mathrm{N}_{2} \mathrm{O}$ in boreal forest soils, interior Alaska, J. Geophys. Res., 108, 8154, doi:10.1029/2001JD000663, 2003.

Kitzler, B., Zechmeister-Boltenstern, S., Holtermann, C., Skiba, U., and Butterbach-Bahl, K.: Controls over $\mathrm{N}_{2} \mathrm{O}, \mathrm{NO}_{\mathrm{x}}$ and $\mathrm{CO}_{2}$ fluxes in a calcareous mountain forest soil, Biogeosciences, 3, 383-395, doi:10.5194/bg-3-383-2006, 2006.

Knorr, K.-H., Glaser, B., and Blodau, C.: Fluxes and ${ }^{13} \mathrm{C}$ isotopic composition of dissolved carbon and pathways of methanogenesis in a fen soil exposed to experimental drought, Biogeosciences, 5, 1457-1473, doi:10.5194/bg-5-1457-2008, 2008.

Knowles, R.: Denitrification, Microbiol. Rev., 46, 43-70, 1982.

Koponen, H. T. and Martikainen, P. J.: Soil water content and freezing temperature affect freeze-thaw related $\mathrm{N}_{2} \mathrm{O}$ production in organic soil, Nutr. Cycl. Agroecosys., 69, 213-219, 2004.

Koponen, H. T., Escudé Duran, C., Maljanen, M., Hytönen, J., and Martikainen, P. J.: Temperature responses of $\mathrm{NO}$ and $\mathrm{N}_{2} \mathrm{O}$ emissions from boreal organic soil, Soil Biol. Biochem., 38, 17791787, doi:10.1016/j.soilbio.2005.12.004, 2006.

Kowalchuk, G. A. and Stephen, J. R.: Ammonia-oxidizing bacteria: A model for molecular microbial ecology, Annu. Rev. Microbiol., 55, 485-529, 2001.

Kurganova, I. N. and Tipe, P.: The effect of freezing-thawing processes on soil respiration activity, Eurasian Soil Sci., 36, 976985, 2003.

Kurganova, I. N., Teepe, R., and de Gerenyu, V. O. L.: The dynamics of $\mathrm{N}_{2} \mathrm{O}$ emission from arable and forest soils under alternating freeze-thaw conditions, Eurasian Soil. Sci., 37, 1219-1228, 2004.

Kurganova, I. N., Teepe, R., and Loftfield, N.: Influence of freeze-thaw events on carbon dioxide emission from soils at different moisture and land use, Carbon Bal. Manage., 2, doi:10.1186/1750-0680-2-2, 2007.

Laville, P., Lehuger, S., Loubet, B., Chaumartin, F., and Cellier, P.: Effect of management, climate and soil conditions on $\mathrm{N}_{2} \mathrm{O}$ and
NO emissions from an arable crop rotation using high temporal resolution measurements, Agr. Forest Meterol., 151, 228-240, doi:10.1016/j.agrformet.2010.10.008, 2011.

Lawrence, C. R., Neff, J. C., and Schimel, J. P.: Does adding microbial mechanisms of decomposition improve soil organic matter models? A comparison of four models using data from a pulsed rewetting experiment, Soil Biol. Biochem., 41, 19231934, 2009.

Lee, X., Wu, H. J., Sigler, J., Oishi, C., and Siccama, T.: Rapid and transient response of soil respiration to rain, Global Change Biol., 10, 1017-1026, 2004.

Lemke, R.: Nitrous oxide emissions from agricultural soils of the Boreal and Parkland regions of Alberta, Soil Sci. Soc. Am. J., 62, 1096-1102, 1998.

Levine, J., Cofer III, W., Sebacher, D., Winstead, E., Sebacher, S., and Boston, P.: The effects of fire on biogenic soil emissions of nitric oxide and nitrous oxide, Global Biogeochem. Cy., 2, 445449, 1988.

Li, C., Frolking, S., and Frolking, T. A.: A model of nitrous oxide evolution from soil driven by rainfall events: 1 . Model structure and sensitivity, J. Geophys. Res., 97, 9759-9776, doi:10.1029/92jd00509, 1992.

Li, C., Aber, J., Stange, F., Butterbach-Bahl, K., and Papen, H.: A process-oriented model of $\mathrm{N}_{2} \mathrm{O}$ and $\mathrm{NO}$ emissions from forest soils: 1. Model development, J. Geophys. Res., 105, 4369-4384, 2000.

Linn, D. M. and Doran, J. W.: Effects of water-filled pore space on carbon dioxide and nitrous oxide production in tilled and nontilled soils, Soil Sci. Soc. Am. J., 48, 1267-1272, 1984.

Liu, S. C., Trainer, M., Fehsenfeld, F. C., Parrish, D. D., Williams, E. J., Fahey, D. W., Hübler, G., and Murphy, P. C.: Ozone production in the rural troposphere and the implications for regional and global ozone distributions, J. Geophys. Res., 92, 4191-4207, doi:10.1029/JD092iD04p04191, 1987.

Maljanen, M., Kohonen, A. R., Virkajarvi, P., and Martikainen, P. J.: Fluxes and production of $\mathrm{N}_{2} \mathrm{O}, \mathrm{CO}_{2}$ and $\mathrm{CH}_{4}$ in boreal agricultural soil during winter as affected by snow cover, Tellus B, 59, 853-859, doi:10.1111/j.1600-0889.2007.00304.x, 2007.

Maljanen, M., Alm, J., Martikainen, P. J., and Repo, T.: Prolongation of soil frost resulting from reduced snow cover increases nitrous oxide emissions from boreal forest soil, Boreal Environ. Res., 15, 34-42, 2010.

Marañón-Jiménez, S., Castro, J., Kowalski, A. S., Serrano-Ortiz, P., Reverter, B. R., Sánchez-Cañete, E. P., and Zamora, R.: Postfire soil respiration in relation to burnt wood management in a Mediterranean mountain ecosystem, Forest Ecol. Manag., 261, 1436-1447, 2011.

Martikainen, P. J.: Nitrous-oxide emission associated with autotrophic ammonium oxidation in acid coniferous forest soil, Appl. Environ. Microb., 50, 1519-1525, 1985.

Martin, R. E., Scholes, M. C., Mosier, A. R., Ojima, D. S., Holland, E. A., and Parton, W. J.: Controls on annual emissions of nitric oxide from soils of the Colorado shortgrass steppe, Global Biogeochem. Cy., 12, 81-91, 1998.

Martin, R. E., Asner, G. P., Ansley, R. J., and Mosier, A. R.: Effects of woody vegetation encroachment on soil nitrogen oxide emissions in a temperate savanna, Ecol. Appl., 13, 897-910, 2003.

Mastepanov, M., Sigsgaard, C., Dlugokencky, E. J., Houweling, S., Strom, L., Tamstorf, M. P., and Christensen, T. R.: Large tundra 
methane burst during onset of freezing, Nature, 456, 628-630, 2008.

Matzner, E. and Borken, W.: Do freeze-thaw events enhance C and $\mathrm{N}$ losses from soils of different ecosystems? A review, Eur. J. Soil Sci., 59, 274-284, 2008.

McCalley, C. K. and Sparks, J. P.: Controls over nitric oxide and ammonia emissions from Mojave Desert soils, Oecologia, 156, 871-881, doi:10.1007/s00442-008-1031-0, 2008.

Meehl, G., Washington, W., Santer, B., Collins, W., Arblaster, J., Hu, A., Lawrence, D., Teng, H., Buja, L., and Strand, W.: Climate change projections for the twenty-first century and climate change commitment in the CCSM3, J. Climate, 19, 2597-2616, 2006.

Miller, A. E., Schimel, J. P., Meixner, T., Sickman, J. O., and Melack, J. M.: Episodic rewetting enhances carbon and nitrogen release from chaparral soils, Soil Biol. Biochem., 37, 2195-2204, 2005.

Misson, L., Rocheteau, A., Rambal, S., Ourcival, J.-M., Limousin, J.-M., and Rodriguez, R.: Functional changes in the control of carbon fluxes after 3 years of increased drought in a Mediterranean evergreen forest?, Global Change Biol., 16, 2461-2475, doi:10.1111/j.1365-2486.2009.02121.x, 2010.

Moore, T. R. and Knowles, R.: Methane emissions from fen, bog and swamp peatlands in Quebec, Biogeochemistry, 11, 45-61, 1990.

Moore, T. R., Roulet, N. T., and Waddington, J. M.: Uncertainty in predicting the effect of climatic change on the carbon cycling of Canadian peatlands, Climatic Change, 40, 229-245, 1998.

Mørkved, P. T., Dörsch, P., Henriksen, T. M., and Bakken, L. R.: $\mathrm{N}_{2} \mathrm{O}$ emissions and product ratios of nitrification and denitrification as affected by freezing and thawing, Soil Biol. Biochem., 38, 3411-3420, 2006.

Müller, C., Martin, M., Stevens, R., Laughlin, R., Kammann, C., Ottow, J., and Jäger, H.: Processes leading to $\mathrm{N}_{2} \mathrm{O}$ emissions in grassland soil during freezing and thawing, Soil Biol. Biochem., 34, 1325-1331, 2002.

Müller, C., Kammann, C., Ottow, J. C. G., and Jäger, H. J.: Nitrous oxide emission from frozen grassland soil and during thawing periods, J. Plant Nutr. Soil Sc., 166, 46-53, 2003.

Muhr, J. and Borken, W.: Delayed recovery of soil respiration after wetting of dry soil further reduces C losses from a Norway spruce forest soil, J. Geophys. Res., 114, G04023, doi:10.1029/2009jg000998, 2009.

Muhr, J., Borken, W., and Matzner, E.: Effects of soil frost on soil respiration and its radiocarbon signature in a Norway spruce forest soil, Global Change Biol., 15, 782-793, 2009.

Muhr, J., Franke, J., and Borken, W.: Drying-rewetting events reduce $\mathrm{C}$ and $\mathrm{N}$ losses from a Norway spruce forest floor, Soil Biol. Biochem., 42, 1303-1312, doi:10.1016/j.soilbio.2010.03.024, 2010.

Neill, C., Steudler, P. A., Garcia-Montiel, D. C., Melillo, J. M., Feigl, B. J., Piccolo, M. C., and Cerri, C. C.: Rates and controls of nitrous oxide and nitric oxide emissions following conversion of forest to pasture in Rondonia, Nutr. Cycl. Agroecosys., 71, 1-15, doi:10.1007/s10705-004-0378-9, 2005.

Neilsen, C. B. G., Groffman, P. M., Hamburg, S. P., and Driscoll, C. T.: Freezing effects on carbon and nitrogen cycling in northern hardwood forest soils, Soil Sci. Soc. Am. J., 65, 1723-1730, 2001.
Nelson, D. W.: Gaseous losses of nitrogen other than through denitrification, in: Nitrogen in agricultural soils, edited by: Stevenson, F. J., American Society of Agronomy, Madison, WI, USA, 327-363, 1982.

Nobre, A. D., Keller, M., Crill, P. M., and Harriss, R. C.: Short-term nitrous oxide profile dynamics and emissions response to water, nitrogen and carbon additions in two tropical soils, Biol. Fert. Soils, 34, 363-373, 2001.

Norman, J., Jansson, P.-E., Farahbakhshazad, N., Butterbach-Bahl, K., Li, C., and Klemedtsson, L.: Simulation of $\mathrm{NO}$ and $\mathrm{N}_{2} \mathrm{O}$ emissions from a spruce forest during a freeze/thaw event using an N-flux submodel from the PnET-N-DNDC model integrated to CoupModel, Ecol. Model., 216, 18-30, 2008.

Öquist, M. and Sundh, I.: Effects of a transient oxic period on mineralization of organic matter to $\mathrm{CH}_{4}$ and $\mathrm{CO}_{2}$ in anoxic peat incubations, Geomicrobiol. J., 15, 325-333, 1998.

Orchard, V. and Cook, F.: Relationship between soil respiration and soil moisture, Soil Biol. Biochem., 15, 447-453, 1983.

Panikov, N. and Dedysh, S.: Cold season $\mathrm{CH}_{4}$ and $\mathrm{CO}_{2}$ emission from boreal peat bogs (West Siberia): Winter fluxes and thaw activation dynamics, Global Biogeochem. Cy., 14, 1071-1080, 2000.

Papen, H. and Butterbach-Bahl, K.: A 3-year continuous record of nitrogen trace gas fluxes from untreated and limed soil of a $\mathrm{N}$ saturated spruce and beech forest ecosystem in Germany -1 . $\mathrm{N}_{2} \mathrm{O}$ emissions, J. Geophys. Res., 104, 18487-18503, 1999.

Paré, D., Boutin, R., Larocque, G. R., and Raulier, F.: Effect of temperature on soil organic matter decomposition in three forest biomes of eastern Canada, Can. J. Soil Sci., 86, 247-256, 2006.

Parkin, T. B.: Effect of sampling frequency on estimates of cumulative nitrous oxide emissions, J. Environ. Qual., 37, 1390-1395, doi:10.2134/jeq2007.0333, 2008.

Parton, W. J., Holland, E. A., Grosso, S. J. D., Hartman, M. D., Martin, R. E., Mosier, A. R., Ojima, D. S., and Schimel, D. S.: Generalized model for $\mathrm{NO}_{\mathrm{x}}$ and $\mathrm{N}_{2} \mathrm{O}$ emissions from soils, J. Geophys. Res., 106, 17403-17419, doi:10.1029/2001jd900101, 2001.

Pesaro, M., Widmer, F., Nicollier, G., and Zeyer, J.: Effects of freeze-thaw stress during soil storage on microbial communities and methidathion degradation, Soil Biol. Biochem., 35, 10491061, 2003.

Pihlatie, M., Ambus, P., Rinne, J., Pilegaard, K., and Vesala, T.: Plant-mediated nitrous oxide emissions from beech (Fagus sylvatica) leaves, New Phytol., 168, 93-98, doi:10.1111/j.14698137.2005.01542.x, 2005.

Poth, M., Anderson, I., Miranda, H., Miranda, A., and Riggan, P.: The magnitude and persistence of soil $\mathrm{NO}, \mathrm{N}_{2} \mathrm{O}, \mathrm{CH}_{4}$, and $\mathrm{CO}_{2}$ fluxes from burned tropical savanna in Brazil, Global Biogeochem. Cy., 9, 503-513, 1995.

Priemé, A. and Christensen, S.: Natural perturbations, dryingwetting and freezing-thawing cycles, and the emission of nitrous oxide, carbon dioxide and methane from farmed organic soils, Soil Biol. Biochem., 33, 2083-2091, 2001.

R Development Core Team: R: A language and environment for statistical computing, R Foundation for Statistical Computing, Vienna, Austria, ISBN 3-900051-07-0, available at: http://www. R-project.org/ (last access: 28 June 2012), 2011.

Raich, J. and Schlesinger, W.: The global carbon dioxide flux in soil respiration and its relationship to vegetation and climate, Tellus 
B, 44, 81-99, 1992.

Ratering, S. and Conrad, R.: Effects of short-term drainage and aeration on the production of methane in submerged rice soil, Global Change Biol., 4, 397-407, 1998.

Regina, K., Syvasalo, E., Hannukkala, A., and Esala, M.: Fluxes of $\mathrm{N}_{2} \mathrm{O}$ from farmed peat soils in Finland, Eur. J. Soil Sci., 55, 591-599, 2004

Rennenberg, $\mathrm{H}$. and Gessler, A.: Consequences of $\mathrm{N}$ deposition to forest ecosystems - Recent results and future research needs, Water Air Soil Poll., 116, 47-64, 1999.

Rey, A., Pegoraro, E., Tedeschi, V., De Parri, I., Jarvis, P. G., and Valentini, R.: Annual variation in soil respiration and its components in a coppice oak forest in Central Italy, Global Change Biol., 8, 851-866, 2002.

Rochette, P., Desjardins, R. L., and Pattey, E.: Spatial and temporal variability of soil respiration in agricultural fields, Can. J. Soil Sci., 71, 189-196, 1991.

Rochette, P., Tremblay, N., Fallon, E., Angers, D. A., Chantigny, M. H., MacDonald, J. D., Bertrand, N., and Parent, L.-É.: $\mathrm{N}_{2} \mathrm{O}$ emissions from an irrigated and non-irrigated organic soil in eastern Canada as influenced by $\mathrm{N}$ fertilizer addition, Eur. J. Soil Sci., 61, 186-196, 2010.

Roelandt, C., Van Wesemael, B., and Rounsevell, M.: Estimating annual $\mathrm{N}_{2} \mathrm{O}$ emissions from agricultural soils in temperate climates, Global Change Biol., 11, 1701-1711, 2005.

Röver, M., Heinemeyer, O., and Kaiser, E.: Microbial induced nitrous oxide emissions from an arable soil during winter, Soil Biol. Biochem., 30, 1859-1865, 1998.

Ruser, R., Flessa, H., Russow, R., Schmidt, G., Buegger, F., and Munch, J. C.: Emission of $\mathrm{N}_{2} \mathrm{O}, \mathrm{N}_{2}$ and $\mathrm{CO}_{2}$ from soil fertilized with nitrate: Effect of compaction, soil moisture and rewetting, Soil Biol. Biochem., 38, 263-274, 2006.

Saetre, P. and Stark, J. M.: Microbial dynamics and carbon and nitrogen cycling following re-wetting of soils beneath two semiarid plant species, Oecologia, 142, 247-260, 2005.

Sawicka, J., Robador, A., Hubert, C., Jørgensen, B., and Brüchert, V.: Effects of freeze-thaw cycles on anaerobic microbial processes in an Arctic intertidal mud flat, ISME J., 4, 585-594, doi:10.1038/ismej.2009.140, 2009.

Schaeffer, S. M., Billings, S. A., and Evans, R. D.: Responses of soil nitrogen dynamics in a Mojave Desert ecosystem to manipulations in soil carbon and nitrogen availability, Oecologia, 134, 547-553, 2003.

Schimel, J. P. and Clein, J. S.: Microbial response to freeze-thaw cycles in tundra and taiga soils, Soil Biol. Biochem., 28, 10611066, 1996

Schimel, J. P. and Mikan, C.: Changing microbial substrate use in Arctic tundra soils through a freeze-thaw cycle, Soil Biol. Biochem., 37, 1411-1418, 2005.

Schimel, J. P., Balser, T. C., and Wallenstein, M.: Microbial stressresponse physiology and its implications for ecosystem function, Ecology, 88, 1386-1394, 2007.

Schlesinger, W. H. and Andrews, J. A.: Soil respiration and the global carbon cycle, Biogeochemistry, 48, 7-20, 2000.

Schlesinger, W. H. and Peterjohn, W. T.: Processes controlling ammonia volatilization from Chihuahuan desert soils, Soil Biol. Biochem., 23, 637-642, 1991.

Schnell, S. and King, G.: Mechanistic analysis of ammonium Inhibition of atmospheric methane consumption in forest soils, Appl.
Environ. Microb., 60, 3514-3521, 1994

Sharma, S., Szele, Z., Schilling, R., Munch, J. C., and Schloter, M.: Influence of freeze-thaw stress on the structure and function of microbial communities and denitrifying populations in soil, Appl. Environ. Microb., 72, 2148-2154, 2006.

Sheffield, J. and Wood, E. F.: Global trends and variability in soil moisture and drought characteristics, 1950-2000, from observation-driven Simulations of the terrestrial hydrologic cycle, J. Climate, 21, 432-458, 2008

Shi, W.-Y., Tateno, R., Zhang, J.-G., Wang, Y.-L., Yamanaka, N., and $\mathrm{Du}, \mathrm{S}$.: Response of soil respiration to precipitation during the dry season in two typical forest stands in the forest-grassland transition zone of the Loess Plateau, Agr. Forest Meteorol., 151, 854-863, doi:10.1016/j.agrformet.2011.02.003, 2011.

Shurpali, N. J., Verma, S. B., Clement, R. J., and Billesbach, D P.: Seasonal distribution of methane flux in a Minnesota peatland measured by eddy-correlation, J. Geophys. Res., 98, 2064920655, 1993

Silver, W. L., Lugo, A. E., and Keller, M.: Soil oxygen availability and biogeochemistry along rainfall and topographic gradients in upland wet tropical forest soils, Biogeochemistry, 44, 301-328, 1999.

Šimùnek, J. and Suarez, D. L.: Modeling of carbon dioxide transport and production in soil: 1. Model development, Water Resour. Res., 29, 487-497, 1993.

Singurindy, O., Molodovskaya, M., Richards, B. K., and Steenhuis, T. S.: Nitrous oxide emission at low temperatures from manureamended soils under corn (Zea mays L.), Agr. Ecosyst. Environ., 132, 74-81, doi:10.1016/j.agee.2009.03.001, 2009.

Sinha, T. and Cherkauer, K. A.: Impacts of future climate change on soil frost in the midwestern United States, J. Geophys. Res., 115, D08105, doi:10.1029/2009jd012188, 2010.

Smart, D. R. and Bloom, A. J.: Wheat leaves emit nitrous oxide during nitrate assimilation, P. Natl. Acad. Sci. USA., 98, 78757878, 2001.

Smart, D. R., Stark, J. M., and Diego, V.: Resource limitations to nitric oxide emissions from a sagebrush-steppe ecosystem, Biogeochemistry, 47, 63-86, 1999.

Smith, J., Wagner-Riddle, C., and Dunfield, K.: Season and management related changes in the diversity of nitrifying and denitrifying bacteria over winter and spring, Appl. Soil Ecol., 44, 138-146, 2010.

Smith, K. A. and Dobbie, K. E.: The impact of sampling frequency and sampling times on chamber-based measurements of $\mathrm{N}_{2} \mathrm{O}$ emissions from fertilized soils, Global Change Biol., 7, 933-945, doi:10.1046/j.1354-1013.2001.00450.x, 2001.

Song, C., Wang, Y., Wang, Y., and Zhao, Z.: Emission of $\mathrm{CO}_{2}, \mathrm{CH}_{4}$ and $\mathrm{N}_{2} \mathrm{O}$ from freshwater marsh during freeze-thaw period in Northeast of China, Atmos. Environ., 40, 6879-6885, 2006.

Sponseller, R. A.: Precipitation pulses and soil $\mathrm{CO}_{2}$ flux in a Sonoran Desert ecosystem, Global Change Biol., 13, 426-436, doi:10.1111/j.1365-2486.2006.01307.x, 2007.

Sponseller, R. A. and Fisher, S. G.: The influence of drainage networks on patterns of soil respiration in a desert catchment, Ecology, 89, 1089-1100, 2008.

Stark, J. M. and Firestone, M. K.: Mechanisms for soil moisture effects on activity of nitrifying bacteria, Appl. Environ. Microb., 61, 218-221, 1995. 
Stark, J. M., Smart, D. R., Hart, S. C., and Haubensak, K. A.: Regulation of nitric oxide emissions from forest and rangeland soils of western North America, Ecology, 83, 2278-2292, 2002.

Steenwerth, K., Pierce, D., Carlisle, E., Spencer, R., and Smart, D.: A vineyard agroecosystem: disturbance and precipitation affect soil respiration under Mediterranean conditions, Soil Sci. Soc. Am. J., 74, 231-239, 2010.

Strack, M. and Waddington, J. M.: Response of peatland carbon dioxide and methane fluxes to a water table drawdown experiment, Global Biogeochem. Cy., 21, Gb1007, doi:10.1029/2006gb002715, 2007.

Striegl, R.: Diffusional limits to the consumption of atmospheric methane by soils, Chemosphere, 26, 715-720, 1993.

Syamsul Arif, M., Houwen, F., and Verstraete, W.: Agricultural factors affecting methane oxidation in arable soil, Biol. Fert. Soils, 21, 95-102, 1996.

Tagesson, T., Mölder, M., Mastepanov, M., Sigsgaard, C., Tamstorf, M. P., Lund, M., Falk, J. M., Lindroth, A., Christensen, T. R., and Ström, L.: Land-atmosphere exchange of methane from soil thawing to soil freezing in a high-Arctic wet tundra ecosystem, Global Change Biol., online first: doi:10.1111/j.13652486.2012.02647.x, 2012.

Teepe, R. and Ludwig, B.: Variability of $\mathrm{CO}_{2}$ and $\mathrm{N}_{2} \mathrm{O}$ emissions during freeze-thaw cycles: results of model experiments on undisturbed forest-soil cores, J. Plant Nutr. Soil Sc., 167, 153159, 2004.

Teepe, R., Brumme, R., and Beese, F.: Nitrous oxide emissions from soil during freezing and thawing periods, Soil Biol. Biochem., 33, 1269-1275, 2001.

Teh, Y. A., Silver, W. L., and Conrad, M. E.: Oxygen effects on methane production and oxidation in humid tropical forest soils, Global Change Biol., 11, 1283-1297, doi:10.1111/j.13652486.2005.00983.x, 2005.

Thauer, R.: Biochemistry of methanogenesis: a tribute to Marjory Stephenson, Microbiology, 144, 2377-2406, 1998.

Tokida, T., Mizoguchi, M., Miyazaki, T., Kagemoto, A., Nagata, O., and Hatano, R.: Episodic release of methane bubbles from peatland during spring thaw, Chemosphere, 70, 165-171, doi:10.1016/j.chemosphere.2007.06.042, 2007.

Turetsky, M. R., Wieder, R. K., and Vitt, D. H.: Boreal peatland $\mathrm{C}$ fluxes under varying permafrost regimes, Soil Biol. Biochem., 34, 907-912, 2002.

Turetsky, M. R., Wieder, R. K., Vitt, D. H., Evans, R., and Scott, K.: The disappearance of relict permafrost in boreal North America: Effects on peatland carbon storage and fluxes, Global Change Biol., 13, 1922-1934, 2007.

Uchida, Y., Clough, T. J., Kelliher, F. M., and Sherlock, R. R.: Effects of aggregate size, soil compaction, and bovine urine on $\mathrm{N}_{2} \mathrm{O}$ emissions from a pasture soil, Soil Biol. Biochem., 40, 924 931, doi:10.1016/j.soilbio.2007.11.007, 2008.

Unger, S., Máguas, C., Pereira, J. S., David, T. S., and Werner, C.: The influence of precipitation pulses on soil respiration - Assessing the "Birch effect" by stable carbon isotopes, Soil Biol. Biochem., 42, 1800-1810, 2010.

Unger, S., Máguas, C., Pereira, J. S., David, T. S., and Werner, C.: Interpreting post-drought rewetting effects on soil and ecosystem carbon dynamics in a Mediterranean oak savannah, Agr. Forest Meteorol., 154-155, 9-18, doi:10.1016/j.agrformet.2011.10.007, 2012. van Bochove, E., Prevost, D., and Pelletier, F.: Effects of freezethaw and soil structure on nitrous oxide produced in a clay soil, Soil Sci. Soc. Am. J., 64, 1638-1643, 2000.

Van der Eerden, L., De Vries, W., and Van Dobben, H.: Effects of ammonia deposition on forests in the Netherlands, Atmos. Environ., 32, 525-532, 1998.

Van Gestel, M., Merckx, R., and Vlassak, K.: Microbial biomass responses to soil drying and rewetting: The fate of fast- and slowgrowing microorganisms in soils from different climates, Soil Biol. Biochem., 25, 109-123, 1993.

van Haren, J. L. M., Handley, L. L., Biel, K. Y., Kudeyarov, V. N., McLain, J. E. T., Martens, D. A., and Colodner, D. C.: Droughtinduced nitrous oxide flux dynamics in an enclosed tropical forest, Global Change Biol., 11, 1247-1257, doi:10.1111/j.13652486.2005.00987.x, 2005.

Vargas, R. and Allen, M. F.: Environmental controls and the influence of vegetation type, fine roots and rhizomorphs on diel and seasonal variation in soil respiration, New Phytol., 179, 460-471, doi:10.1111/j.1469-8137.2008.02481.x, 2008.

Vargas, R., Baldocchi, D. D., Allen, M. F., Bahn, M., Black, T. A., Collins, S. L., Yuste, J. C., Hirano, T., Jassal, R. S., Pumpanen, J., and Tang, J. W.: Looking deeper into the soil: biophysical controls and seasonal lags of soil $\mathrm{CO}_{2}$ production and efflux, Ecol. Appl., 20, 1569-1582, 2010a.

Vargas, R., Detto, M., Baldocchi, D. D., and Allen, M. F.: Multiscale analysis of temporal variability of soil $\mathrm{CO}_{2}$ production as influenced by weather and vegetation, Global Change Biol., 16, 1589-1605, doi:10.1111/j.1365-2486.2009.02111.x, 2010b.

Vargas, R., Carbone, M., Reichstein, M., and Baldocchi, D.: Frontiers and challenges in soil respiration research: from measurements to model-data integration, Biogeochemistry, 102, 1-13, doi:10.1007/s10533-010-9462-1, 2011.

Virkajärvi, P., Maljanen, M., Saarijärvi, K., Haapala, J., and Martikainen, P. J.: $\mathrm{N}_{2} \mathrm{O}$ emissions from boreal grass and grass clover pasture soils, Agr. Ecosyst. Environ., 137, 59-67, 2010.

Vogt, K., Grier, C., and Vogt, D.: Production, turnover, and nutrient dynamics of above- and belowground detritus of world forests, Adv. Ecol. Res., 15, 303-377, 1986.

Wagner-Riddle, C., Furon, A., McLaughlin, N. L., Lee, I., Barbeau, J., Jayasundara, S., Parkin, G., Von Bertoldi, P., and Warland, J.: Intensive measurement of nitrous oxide emissions from a corn-soybean-wheat rotation under two contrasting management systems over 5 years, Global Change Biol., 13, 1722-1736, doi:10.1111/j.1365-2486.2007.01388.x, 2007.

Wagner-Riddle, C., Hu, Q., Van Bochove, E., and Jayasundara, S.: Linking nitrous oxide flux during spring thaw to nitrate denitrification in the soil profile, Soil Sci. Soc. Am. J., 72, 908-916, doi:10.2136/sssaj2007.0353, 2008.

Wagner-Riddle, C., Rapai, J., Warland, J., and Furon, A.: Nitrous oxide fluxes related to soil freeze and thaw periods identified using heat pulse probes, Can. J. Soil Sci., 90, 409-418, 2010.

Walter, K. M., Zimov, S. A., Chanton, J. P., Verbyla, D., and Chapin, F. S.: Methane bubbling from Siberian thaw lakes as a positive feedback to climate warming, Nature, 443, 71-75, doi:10.1038/nature05040, 2006.

West, A. E. and Schmidt, S. K.: Wetting stimulates atmospheric $\mathrm{CH}_{4}$ oxidation by alpine soil, FEMS Microbiol. Ecol., 25, 349353, 1998. 
Whittenbury, R., Davies, S. L., and Davey, J. F.: Exospores and cysts formed by methane-utilizing bacteria, J. Gen. Microbiol., 61, 219-226, doi:10.1099/00221287-61-2-219, 1970.

Williams, E. J., Hutchinson, G. L., and Fehsenfeld, F. C.: Nitrogen oxides and nitrous oxide emissions from soil, Global Biogeochem. Cy., 6, 351-388, doi:10.1029/92GB02124, 1992.

Wolf, B., Zheng, X., Bruggemann, N., Chen, W., Dannenmann, M., Han, X., Sutton, M. A., Wu, H., Yao, Z., and ButterbachBahl, K.: Grazing-induced reduction of natural nitrous oxide release from continental steppe, Nature, 464, 881-884, doi:10.1038/nature08931, 2010.

Wolf, B., Kiese, R., Chen, W., Grote, R., Zheng, X., and ButterbachBahl, K.: Modeling $\mathrm{N}_{2} \mathrm{O}$ emissions from steppe in Inner Mongolia, China, with consideration of spring thaw and grazing intensity, Plant Soil, 350, 297-310, doi:10.1007/s11104-011-0908-6, 2012.

Wrage, N., Velthof, G. L., van Beusichem, M. L., and Oenema, O.: Role of nitrifier denitrification in the production of nitrous oxide, Soil Biol. Biochem., 33, 1723-1732, 2001.

Wu, X., Brüggemann, N., Gasche, R., Shen, Z., Wolf, B., and Butterbach-Bahl, K.: Environmental controls over soilatmosphere exchange of $\mathrm{N}_{2} \mathrm{O}, \mathrm{NO}$, and $\mathrm{CO}_{2}$ in a temperate Norway spruce forest, Global Biogeochem. Cy., 24, GB2012, doi:10.1029/2009gb003616, 2010a.

Wu, X., Yao, Z., Brüggemann, N., Shen, Z. Y., Wolf, B., Dannenmann, M., Zheng, X., and Butterbach-Bahl, K.: Effects of soil moisture and temperature on $\mathrm{CO}_{2}$ and $\mathrm{CH}_{4}$ soil-atmosphere exchange of various land use/cover types in a semi-arid grassland in Inner Mongolia, China, Soil Biol. Biochem., 42, 773-787, $2010 b$.

Xiang, S.-R., Doyle, A., Holden, P. A., and Schimel, J. P.: Drying and rewetting effects on $\mathrm{C}$ and $\mathrm{N}$ mineralization and microbial activity in surface and subsurface California grassland soils, Soil Biol. Biochem., 40, 2281-2289, 2008.

Xu, L. K., Baldocchi, D. D., and Tang, J. W.: How soil moisture, rain pulses, and growth alter the response of ecosystem respiration to temperature, Global Biogeochem. Cy., 18, GB4002, doi:10.1029/2004GB002281, 2004.

Xu, L., Furtaw, M. D., Madsen, R. A., Garcia, R. L., Anderson, D. J., and McDermitt, D. K.: On maintaining pressure equilibrium between a soil $\mathrm{CO}_{2}$ flux chamber and the ambient air, J. Geophys. Res., 111, D08S10, doi:10.1029/2005jd006435, 2006.
$\mathrm{Xu}, \mathrm{M}$. and Qi, Y.: Soil-surface $\mathrm{CO}_{2}$ efflux and its spatial and temporal variations in a young ponderosa pine plantation in northern California, Global Change Biol., 7, 667-677, 2001.

Xu, X. K., Han, L., Luo, X. B., Liu, Z. R., and Han, S. J.: Effects of nitrogen addition on dissolved $\mathrm{N}_{2} \mathrm{O}$ and $\mathrm{CO}_{2}$ dissolved organic matter, and inorganic nitrogen in soil solution under a temperate old-growth forest, Geoderma, 151, 370-377, doi:10.1016/j.geoderma.2009.05.008, 2009.

Yanai, Y., Toyota, K., and Okazaki, M.: Effects of charcoal addition on $\mathrm{N}_{2} \mathrm{O}$ emissions from soil resulting from rewetting air-dried soil in short-term laboratory experiments, Soil Sci. Plant Nutr., 53, 181-188, 2007.

Yao, Z., Wu, X., Wolf, B., Dannenmann, M., Butterbach-Bahl, K., Brüggemann, N., Chen, W., and Zheng, X.: Soil-atmosphere exchange potential of $\mathrm{NO}$ and $\mathrm{N}_{2} \mathrm{O}$ in different land use types of Inner Mongolia as affected by soil temperature, soil moisture, freeze-thaw, and drying-wetting events, J. Geophys. Res., 115, D17116, doi:10.1029/2009jd013528, 2010.

Yergeau, E. and Kowalchuk, G.: Responses of Antarctic soil microbial communities and associated functions to temperature and freeze-thaw cycle frequency, Environ. Microbiol., 10, 2223 2235, 2008.

Yienger, J. J. and Levy II, H.: Empirical model of global soilbiogenic $\mathrm{NO}_{\mathrm{x}}$ emissions, J. Geophys. Res., 100, 11447-11464, doi:10.1029/95jd00370, 1995.

Yu, J., Sun, W., Liu, J., Wang, J., Yang, J., and Meixner, F. X.: Enhanced net formations of nitrous oxide and methane underneath the frozen soil in Sanjiang wetland, northeastern China, J. Geophys. Res., 112, D07111, doi:10.1029/2006JD008025, 2007.

Yuste, J. C., Janssens, I. A., Carrara, A., Meiresonne, L., and Ceulemans, R.: Interactive effects of temperature and precipitation on soil respiration in a temperate maritime pine forest, Tree Physiol., 23, 1263-1270, 2003.

Zhu, R. B., Liu, Y. S., Ma, E. D., Sun, J. J., Xu, H., and Sun, L. G.: Greenhouse gas emissions from penguin guanos and ornithogenic soils in coastal Antarctica: Effects of freezing-thawing cycles, Atmos. Environ., 43, 2336-2347, doi:10.1016/j.atmosenv.2009.01.027, 2009.

Zsolnay, A. and Gorlitz, H.: Water extractable organic matter in arable soils: effects of drought and long-term fertilization, Soil Biol. Biochem., 26, 1257-1261, 1994. 